Atmos. Chem. Phys., 18, 13215-13230, 2018

https://doi.org/10.5194/acp-18-13215-2018

(C) Author(s) 2018. This work is distributed under

the Creative Commons Attribution 4.0 License.

\title{
Source apportionment of atmospheric aerosol in a marine dusty environment by ionic/composition mass balance (IMB)
}

\author{
João Cardoso ${ }^{1,2}$, Susana M. Almeida ${ }^{3}$, Teresa Nunes ${ }^{1}$, Marina Almeida-Silva ${ }^{3}$, Mário Cerqueira ${ }^{1}$, Célia Alves ${ }^{1}$, \\ Fernando Rocha ${ }^{4}$, Paula Chaves ${ }^{3}$, Miguel Reis ${ }^{3}$, Pedro Salvador ${ }^{5}$, Begoña Artiñano ${ }^{5}$, and Casimiro Pio ${ }^{1}$ \\ ${ }^{1}$ CESAM \& Dep. Environ, Aveiro University, Aveiro, Portugal \\ ${ }^{2}$ Department of Science and Technology, Cape Verde University, Praia, Cabo Verde \\ ${ }^{3} \mathrm{TN}$, Instituto Superior Técnico, Lisbon University, Bobadela, Portugal \\ ${ }^{4}$ Geobiotec \& Dep. Geosciences, Aveiro University, Aveiro, Portugal \\ ${ }^{5}$ Environ Dep, CIEMAT, Madrid, Spain
}

Correspondence: Casimiro Pio (casimiro@ua.pt)

Received: 3 January 2018 - Discussion started: 2 March 2018

Revised: 17 August 2018 - Accepted: 23 August 2018 - Published: 13 September 2018

\begin{abstract}
PM}_{10}$ aerosol was sampled in Santiago, the largest island of Cabo Verde, for 1 year, and analysed for elements, ions and carbonaceous material. Very high levels of dust were measured during the winter months, as a result of the direct transport of dust plumes from the African continent. Ionic and mass balances (IMBs) were applied to the analysed compounds, permitting the determination of six to seven different processes and source contributions to the aerosol loading: insoluble and soluble dust, sea salt, carbonaceous material and secondary inorganic compounds resulting from the reaction of acidic precursors with ammonia, sea salt and dust. The mass balance could be closed by the consideration and estimation of sorbed water that constituted $20 \%-30 \%$ of the aerosol mass. The balance methodology was compared with positive matrix factorisation (PMF), showing similar qualitative source composition. In quantitative terms, while for soil dust and secondary inorganic compound source classes, the results are similar, for other sources such as sea-salt spray there are significant differences in periods of dust episodes. The discrepancies between both approaches are interpreted based on calculated source profiles. The joint utilisation of the two methodologies, which are complementary, gives confidence in our capability for the correct source apportionment of aerosol particles.
\end{abstract}

\section{Introduction}

Atmospheric aerosol has an important role in atmospheric physics and chemistry (Lohmann and Feichter, 2005; Pöschl, 2005) and significant impacts on climate (Buseck and Pósfai, 1999; Ramanatham et al., 2001) and human health (Pope, 2000; Brunekreef and Fosberg, 2005; Tobias et al., 2011).

Atmospheric aerosol is both the result of gas-to-particle transformation from natural or anthropogenically induced precursors and of direct emissions from the Earth's surface by the action of wind on soil and water. Gas-to-particle transformation gives fundamentally fine (submicrometre) particles, while wind-induced mechanic processes on the planet's surface produce mostly coarse particles as sea salt over the oceans or soil dust over deserts and other bare soil areas (Seinfeld and Pandis, 1998). On a global scale, sea spray and dust are highly dominant, in terms of suspended mass and regions affected, by comparison with other aerosol sources (Raes et al., 2000; Tanaka and Chiba, 2006). Although mostly natural, coarse aerosol particles associated with dust emissions are frequently affected by anthropogenic activities such as industry, transportation and agricultural practices at urban and regional/hemispheric scales (Almeida et al., 2006a; Ginoux et al., 2012).

It is important to know quantitatively the sources of atmospheric aerosols in order to correctly implement strategies and measures to control and reduce atmospheric particulate pollution and its effects on nature and humankind. There is an array of methodologies to evaluate the impact of sources 
and precursors on atmospheric particulate loading that range from emission, dispersion and transport modelling, to source apportionment techniques (Blanchard, 1999). Source apportionment techniques use information on aerosol atmospheric composition and concentrations, at one or several locations, to infer quantitatively the sources and processes responsible for the particulate loading at the receptor (Almeida et al., 2006b; Belis et al., 2013).

In source apportionment, when the number and composition of the sources are unknown, multivariate analysis, based on particulate composition variability at the receptor(s) as a function of time, is a very common and useful methodology to quantitatively evaluate the main sources of atmospheric particulate matter (Ashbaugh et al., 1984; Henry et al., 1984; Hopke, 1985). Presently, the most used multivariate analysis methodology is positive matrix factorisation (PMF), because it allows the discrimination of only positive values in both source profiles and contributions (Paatero and Tapper, 1994; Paatero, 1999; Reff et al., 2007; Amato et al., 2016).

Source apportionment multivariate methodologies permit frequently to identify the impact of the majority of direct sources and gas-to-particle conversion processes and their variability in time, during the aerosol measured period. If associated with statistical backward trajectory analysis, the method also permits the determination of source regions during regional and, principally, long-range transport (Salvador et al., 2016).

Multivariate methods, although very useful, are not perfect and have uncertainties resulting from collinearity of sources, the evolution of composition during transport, etc. that need to be detected and estimated (Belis et al., 2013). When a large number of compounds and elements is determined by chemical analysis of aerosol samples, an alternative methodology can be used to infer the total aerosol composition, which takes into account that the total aerosol mass is the sum of the mass of the individual components. Also from the chemical analysis, it is possible to intercompare analysed anions and cations, which have to obey the principle of electroneutrality. From the mass and ionic composition, it is frequently viable to infer quantitatively the origin of the aerosol, because many of the analysed constituents are tracers of specific sources.

Ionic and mass balances (IMBs) rely mostly on the direct measurement of aerosol constituents and therefore are less affected by indemonstrable assumptions, as it happens in the assignment of the number of factors and their identities, in multivariate methods such as PMF (Belis et al., 2014). Mass balance has been frequently applied in the past but mostly as a screening tool (Watson et al., 2002). However, if properly applied, ionic and mass balances have the potential to correctly perform the source apportionment of atmospheric aerosol. We would like to emphasise that the European Guide on Air Pollution Source Apportionment with Receptor Models (Belis et al., 2014) exhorts to use receptor models in combination with independent methodologies to achieve more ro- bust estimations by mutual validation of the outputs. Our objective in this paper is thus to develop and apply a detailed ionic and mass balance to aerosol particles in a dusty marine environment, demonstrating the capability of this methodology to determine the aerosol sources with an accuracy as good as that of the most developed multivariate methods, such as PMF.

\section{Mass balance methodologies}

Composition and mass balance is feasible when the main components of the aerosol sources, such as soil elements, sea-salt constituents, inorganic water soluble ions and carbonaceous mass, are measured and quantified (Sciare et al., 2005; Guinot et al., 2007; Grigoratos et al., 2014; Genga et al., 2017). Even when there is a thorough quantification of aerosol constituents, it is not often possible to apportion more than $70 \%$ to $80 \%$ of measured aerosol total mass, because important elemental constituents of particulate matter, such as oxygen, in water, soil and organic carbon, are not usually analysed (Malm et al., 1994; Andrews et al., 2000; Rees et al., 2004; Perrino et al., 2013; Grigoratos et al., 2014). Oxygen is the most abundant element in the Earth's crust, constituting on average $47 \%$ of the continental crust mass (Wedepohl, 1995).

For mass balance purposes, the determination of soil contribution is, usually, inferred from the analysis of the major soil elements measured in the aerosol samples ( $\mathrm{Si}, \mathrm{Al}, \mathrm{Fe}$, $\mathrm{Mn}, \mathrm{Ti}$, etc.), taking into account the presence of their oxides:

Soil dust mass $=\mathrm{SiO}_{2}+\mathrm{Al}_{2} \mathrm{O}_{3}+\mathrm{Fe}_{2} \mathrm{O}_{3}+\mathrm{MnO}$

$$
+\mathrm{TiO}_{2}+\text { etc. }
$$

Depending on the completeness of the soil elemental analysis and the composition knowledge of the source soils, it is possible to adapt the above equation to better apportion the soil mass by mass balance (Formenti et al., 2001; Eldred, 2003; Andrews et al., 2000, and references therein):

Soil dust mass $=F(2.14 \mathrm{Si}+1.89 \mathrm{Al}+1.43 \mathrm{Fe}$

$$
+1.39 \mathrm{Mn}+1.67 \mathrm{Ti}+\text { etc. })
$$

where $F$ is a multiplying factor that takes into account the unmeasured material (such as elements and the presence of hydrated water) in the soil dust.

The sea-salt contribution is evaluated by considering that emitted sea-salt spray has the composition of salt in seawater. A possible exception is chloride that frequently appears in lower ratios due to sea-salt spray interaction with atmospheric acids, such as $\mathrm{HNO}_{3}, \mathrm{H}_{2} \mathrm{SO}_{4}$ or $\mathrm{SO}_{2}$, which results in the evaporation of $\mathrm{Cl}^{-}$, as $\mathrm{HCl}$. The $\mathrm{Cl}^{-}$in the particulate phase can be, partially, or totally, substituted by $\mathrm{NO}_{3}^{-}$, or $\mathrm{SO}_{4}^{2-}$, in the form of secondary sodium and magnesium nitrates and sulfates (Pio and Lopes, 1998). A similar reaction 
can take place between these atmospheric strong acids and dust, resulting, for example, in the partial or total vaporisation of carbonates, as $\mathrm{CO}_{2}$, and the formation of secondary calcium nitrates and sulfates (Pio et al., 1994; Goodman et al., 2000).

Soil carbonates are part of the carbonaceous aerosol. As they are infrequently analysed, in source apportionment they have to be approximately inferred from calcium and magnesium measurements. In dusty environments, the measurement of carbonates is important to permit a more correct composition/mass balance source apportionment.

Another component of the carbonaceous aerosol is the organic mass. This component is usually calculated from the measurement of organic carbon by applying a multiplication factor to take into account other unmeasured elements such as nitrogen, sulfur and, principally, oxygen. Factors ranging from 1.2 to 2.3 have been employed for this purpose (Countess et al., 1980; Japar et al., 1984; Rogge et al., 1993a, b; Sempere and Kawamura, 1994; Russel, 2003; Chen and Yu, 2007; El-Zanan et al., 2009). The highest values are commonly used in sites affected by biomass burning emissions, rich in sugars and organic acids, or away from emission sources, because, under these conditions, the precursor organic material had plenty of time to be strongly oxidised (Turpin and Lim, 2001; Sciare et al., 2005; Ervens et al., 2011). Genga et al. (2017) used variable values between 1.8 and 2.1, depending on the direction of the wind, to best fit the mass closure process in a Mediterranean port city.

Water is a common and important component of atmospheric aerosol that may constitute up to $20 \%$ of the total PM mass (Canepari et al., 2013; Perrino et al., 2013). Model calculations estimate that particle-bound water constitutes $20 \%-35 \%$ of the annual mean European atmospheric PM concentrations (Tsyro, 2005). In spite of that, only in a few studies has aerosol particulate water been indirectly or directly estimated (Dick et al., 2000; Rees et al., 2004; Stanier et al., 2004; Speer et al., 1997, 2003; Kitamori et al., 2009).

Several attempts have been made and published to account for water in sampled aerosols. Using a thermodynamic equilibrium ion modelling, temperature, humidity and inorganic ions concentrations, Chen et al. (2014) estimated that water constituted up to $38 \%$ of the $\mathrm{PM}_{2.5}$ mass in the heavily polluted atmosphere of Beijing for aerosols weighted at $40 \%$ relative humidity $(\mathrm{RH})$. To estimate strongly bound water, Harrison et al. (2003), in samples weighted at 45\%-50\% $\mathrm{RH}$, applied a hydration multiplication factor of 1.29 to the measured sulfates and nitrates (as ammonium and/or sodium compounds). Sciare et al. (2005) and Genga et al. (2017) successfully used this methodology to close the mass balance in Mediterranean aerosols.

During laboratory studies with water and sea-salt particles, Tang et al. (1997) found the presence of a hysteresis supersaturation when decreasing relative humidity, with sudden efflorescence at $47 \%$ RH. Depending on whether the particles were in a dry or wet state, the ratio of water to dry sea-salt masses observed at $50 \%$ RH was 0.4 , or 1.4 , respectively.

Tang and Munkelwitz (1994) and Xu et al. (1998) determined the water content in ammonium sulfate. A water/salt ratio of 0.4 was obtained at $50 \% \mathrm{RH}$ in liquid meta-state equilibrium. A ratio of 0.45 was employed to calculate the water contribution to ammonium sulfate aerosols by Speer et al. (2003).

Speer et al. (2003) also estimated the water content in organic aerosol particles. A relationship between the excess liquid water and the measured organic carbon mass was found. Through modelling it was determined that, on average, about $80 \%$ of the liquid water in the $\mathrm{PM}_{2.5}$ could be accounted for by inorganic ions, with the remaining $20 \%$ associated with organic compounds. The liquid water to organic carbon mass ratio, at $50 \%$, was estimated as 0.2 (an OM/OC value of 2 was considered).

\section{Experimental}

The present work uses data from the field campaign of the CV-DUST (Atmospheric aerosol in the Cabo Verde region: carbon and soluble fractions of $\mathrm{PM}_{10}$ ) project, which took place on Santiago island, Cabo Verde, between January 2011 and January 2012. Atmospheric aerosol and ancillary measurements were performed on the roof platform of the Cape Verde Meteorological Institute, on the outskirts of Praia $\left(14.92^{\circ} \mathrm{N}, 23.48^{\circ} \mathrm{W}\right), 98 \mathrm{~m}$ a.s.1. and approximately $1.7 \mathrm{~km}$ from the sea border. During the sampling period, daily averaged temperatures and $\mathrm{RH}$ ranged from 21 to $29^{\circ} \mathrm{C}$ and from $50 \%$ to $86 \%$, respectively. Total rainfall was only $152 \mathrm{~mm}$, concentrated in the months of August to October.

$\mathrm{PM}_{10}$ aerosol particles were collected, in parallel, onto three filter types (quartz fibre, Teflon and Nuclepore membranes) with high-volume and low-volume samplers, equipped with $\mathrm{PM}_{10}$ inlets. A total of 140 events were sampled, with filtering periods ranging from 6 to $96 \mathrm{~h}$ (the low sampling periods during Saharan dust episodes) allowing the collection of enough aerosol material for all necessary analysis without the risk of clogging the filters during dust storms. Taking into account the variable extension of sampling periods, in this publication, all the calculated concentration averages are weighted by the sampling time.

Details of sampling and filter analysis are given elsewhere (Almeida-Silva, 2014; Salvador et al., 2016); here, we only provide a summary of published information. Filters were weighted with semi-micro- or microbalances to determine $\mathrm{PM}_{10}$ total mass, at $50 \% \mathrm{RH}$ and $20^{\circ} \mathrm{C}$. Mass concentrations measured in the three parallel sampling lines compared quite well ( $R=0.99$; best-fit lines with $y / x=0.98-1.02$; for details, see Fig. S1 in the Supplement), a confirmation that the filters were sampling the same aerosol population. 
Nuclepore filters were employed to determine particulate elemental content using particle-induced X-ray emission (PIXE) and/or $k_{0}$-instrumental neutron activation analysis ( $k_{0}$-INAA) (Almeida et al., 2013; Almeida-Silva, 2014). A total of 26 elements was measured by the two techniques, although some light elements, such as $\mathrm{Na}$ and $\mathrm{Cl}$, could only be quantified with large uncertainties, characteristic of the analytical conditions and techniques.

The quartz filters were used to determine carbonates by acid evolution and non-dispersive infrared analysis of evolved $\mathrm{CO}_{2}$ (Pio et al., 1994) and elemental carbon (EC) plus organic carbon (OC), with a homemade thermo-optical carbon analyser, after pre-removal of carbonates with $\mathrm{HCl}$ fumes (Pio et al., 2011).

Water-soluble anions and cations, sampled in Teflon filters, were measured by ion chromatography. The method permitted the quantification of $\mathrm{NH}_{4}^{+}, \mathrm{Na}^{+}, \mathrm{Mg}^{2+}$ and $\mathrm{K}^{+}$ cations, and $\mathrm{SO}_{4}^{2-}, \mathrm{NO}_{3}^{-}$and $\mathrm{Cl}^{-}$anions. Comparison between total cation and anion equivalents indicates a clear excess of cations ( $42 \%$, on average). Inclusion of independently measured carbonates in the ionic balance brings the ratio of cations to anions to 0.93 , demonstrating the importance of carbonate measurements for a more complete aerosol characterisation in dusty environments (see Fig. S2 in the Supplement for details).

\section{Results and discussion}

\section{1 $\mathrm{PM}_{10}$ mass and components}

As reported elsewhere (Almeida-Silva, 2013; Pio et al., 2014; Salvador et al., 2016), Cabo Verde has two distinct atmospheric pollution seasons. During winter months (December-February) the atmospheric boundary layer is impacted by important dust intrusions from the Saharan region, with daily averaged $\mathrm{PM}_{10}$ concentrations going up to hundreds of $\mu \mathrm{g} \mathrm{m}^{-3}$ (see Fig. 1 and Table 1). This period is locally designated as "Bruma-Seca", meaning "dry haze".

During May-September, there is no direct intrusion of dust plumes from Africa, at lower atmospheric levels, in the boundary layer (represented by a blue shade mask in Fig. 1), and we call it dust-free season. During the dust-free period, the atmosphere contains still important quantities of dust originating either from the island arid surface or from continuous dust transport from Africa into the region across the free troposphere, which partially sediments to lower atmospheric levels (Gama et al., 2015). The months of March, April, October and November have intermittent direct intrusions of Saharan dust, with $\mathrm{PM}_{10}$ concentrations sometimes reaching $100 \mu \mathrm{g} \mathrm{m}^{-3}$. Throughout this document, we present average results for the total sampling period and for the two dry-haze and dust-free seasons.

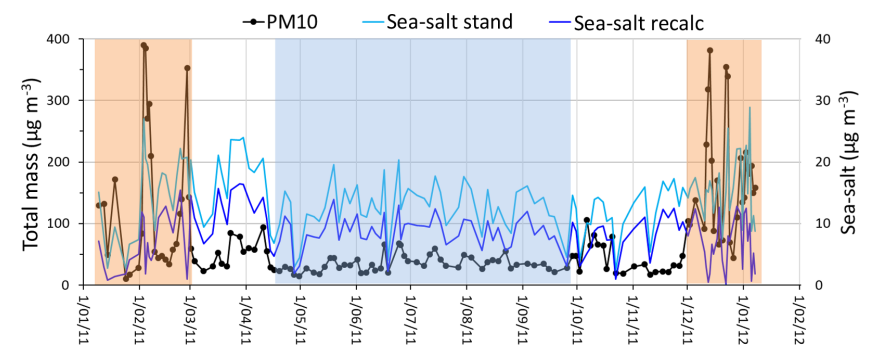

Figure 1. Levels of $\mathrm{PM}_{10}$ and sea salt along the annual sampling period. Shades of brown and blue represent, respectively, periods clearly with (dry haze) and without (dust-free) dust plume direct intrusions. "Sea-salt stand" indicates concentrations of sea-salt spray calculated by considering $\mathrm{Na}^{+}$as an exclusive tracer of marine emissions. "Sea-salt recalc" represents sea-salt levels estimated after removal of soil dust $\mathrm{Na}^{+}$and $\mathrm{Mg}^{2+}$.

Table 1. Weighted average concentrations of $\mathrm{PM}_{10}$, major elements, ions and carbon fractions for the total campaign and for dry-haze and dust-free seasons. $\mathrm{Na}$ and $\mathrm{Cl}$ (in bold) were measured with important inaccuracies, as evidenced by comparison with the respective water-soluble ion concentrations.

\begin{tabular}{|c|c|c|c|}
\hline & $\begin{array}{l}\text { Year average } \\
\quad\left(\mathrm{ng} \mathrm{m}^{-3}\right)\end{array}$ & $\begin{array}{l}\text { Dry haze } \\
\left(\mathrm{ng} \mathrm{m}^{-3}\right)\end{array}$ & $\begin{array}{l}\text { Dust-free } \\
\left(\mathrm{ng} \mathrm{m}^{-3}\right)\end{array}$ \\
\hline $\mathrm{PM}_{10}$ & 59602 & 117000 & 33900 \\
\hline $\mathrm{Si}$ & 6595 & 17100 & 2150 \\
\hline $\mathrm{Al}$ & 3814 & 9930 & 1220 \\
\hline $\mathbf{N a}$ & 3230 & 3440 & 3040 \\
\hline $\mathrm{Fe}$ & 1835 & 4560 & 721 \\
\hline $\mathrm{Ca}$ & 1450 & 2920 & 783 \\
\hline $\mathrm{Mg}$ & 969 & 2130 & 454 \\
\hline $\mathrm{K}$ & 772 & 1580 & 380 \\
\hline $\mathrm{Ti}$ & 197 & 454 & 93 \\
\hline $\mathrm{Ba}$ & 31 & 66 & 21 \\
\hline $\mathrm{Mn}$ & 31 & 78 & 12 \\
\hline Cl & 4660 & 5810 & 3930 \\
\hline$S$ & 852 & 941 & 792 \\
\hline $\mathrm{Na}^{+}$ & 4047 & 4360 & 3760 \\
\hline $\mathrm{Ca}^{2+}$ & 818 & 1540 & 475 \\
\hline $\mathrm{Mg}^{2+}$ & 386 & 443 & 351 \\
\hline $\mathrm{K}^{+}$ & 240 & 251 & 166 \\
\hline $\mathrm{NH}_{4}^{+}$ & 213 & 101 & 257 \\
\hline $\mathrm{Cl}^{-}$ & 5344 & 5770 & 4840 \\
\hline $\mathrm{SO}_{4}^{2-}$ & 1898 & 1880 & 1880 \\
\hline $\mathrm{NO}_{3}^{-}$ & 1191 & 1250 & 115 \\
\hline $\mathrm{CO}_{3}^{2-}$ & 816 & 2230 & 169 \\
\hline $\mathrm{EC}$ & 188 & 110 & 270 \\
\hline $\mathrm{OC}$ & 980 & 1340 & 870 \\
\hline
\end{tabular}

\subsection{Soil and sea-salt sources}

$\mathrm{PM}_{10}$ in Cabo Verde is mainly influenced by emissions from soil and sea surfaces (Gama et al., 2015). The determina- 
tion of the soil contribution, by composition/mass balance, can be improved from the knowledge of source soil composition. When information on dust-originated soil is unavailable, average global upper continental crust composition is frequently employed (Mason and Moore, 1982; Wedepohl, 1995). In our case, dust is almost exclusively originating from the north African Sahara and Sahel, and information on regional soil composition for these regions is available.

There is a handful of publications on soil composition in north Africa, which provide evidence of a wide composition variability across the Saharan and sub-Saharan regions (Guieu et al., 2002; Journet et al., 2014; Scheuvens et al., 2013, and references therein). One of the most complete Saharan soil data sets was given by the IDAEA-CSIC research group (Moreno et al., 2006). The publication provides the concentrations of 47 elements in the bulk soil of nine locations, across four regions, in north Africa (Hoggar massif, Chad Basin, Niger and western Sahara). Castillo et al. (2008) provides soil size distributed composition information for the same sites. We used this data set to infer the composition and mass balance of soil dust in our samples (Table S1, in the Supplement, adapted from Moreno et al., 2006, shows compound average contributions).

Saharan soil composition in Moreno et al. (2006) reveals some differences by comparison with the average crust/upper crust (Mason and Moore, 1986; Wedepohl, 1995), with a relative enrichment of $\mathrm{Si}$ and $\mathrm{Ti}$, probably as a result of intense weathering of Sahara desert soils. Si and Ti form rather hard crystals (silica and rutile), resistant to physical weathering. The size chemical speciation of Saharan soils by Castillo et al. (2008) revealed $\mathrm{Al}, \mathrm{Mg}$ and Fe moderate enrichments, in suspended finer particles, in contrast to $\mathrm{K}$, which had increased concentrations at coarser sizes.

Aerosols generated by suspension from Sudan desert soil have also shown an $\mathrm{Al}$ enrichment, while there has been an impoverishment in $\mathrm{Si}$ and $\mathrm{Ti}$ elements in smaller particles (Eltayeb et al., 2001). The ratio of $\mathrm{Al} / \mathrm{Si}$ in suspended dust decreased with increasing particle size. A similar behaviour occurred in the ratio of $\mathrm{Al} / \mathrm{Ti}$ for particles $<45 \mu \mathrm{m}$. The authors attributed this behaviour to the presence of large quartz crystals in soil and their substitution in dust by smaller particles of alkali-plagioclase and clay minerals.

Journet et al. (2014) concluded that, in desert soils, silica minerals accumulate preferably in the silt fraction $\left(2 \mu \mathrm{m}<D_{p}<65 \mu \mathrm{m}\right)$, while kaolinite and other clay minerals are mostly concentrated in the clay size fraction $\left(D_{p}<2 \mu \mathrm{m}\right)$; kaolinite that has a $\mathrm{Al} / \mathrm{Si}$ ratio of 0.95 is the main mineral of desert areas. The authors assumed that the mineral composition of airborne dust is broadly similar to that of the clay size fraction in the desert soil.

Taking into account the previous information, we speculate that, as a result of soil weathering, particles containing $\mathrm{Si}$ are heavier/larger than other soil particles and therefore are more difficultly suspended by the wind and exported to other regions, enriching local soils.
Consequently, it is expectable that Saharan suspended dust will be impoverished in $\mathrm{Si}$ and $\mathrm{Ti}$, by comparison with less hard minerals containing $\mathrm{Al}, \mathrm{Fe}, \mathrm{Mg}, \mathrm{Na}$, etc. This is observed in our aerosol samples where there is a quite constant $\mathrm{Al} / \mathrm{Si}$ mass ratio of 0.61 , independent from the period of the year or the air mass trajectories $\left(\mathrm{Al}=0.61 \mathrm{Si}-254 \mathrm{ng} \mathrm{m}^{-3}\right.$; $R=0.99$ ). Comparison between prevalently soil-originated elements, showed that, for $\mathrm{Al}, \mathrm{Fe}$ and $\mathrm{Mn}$, the concentration ratios in the aerosol are similar to those in average crustal material and within the limits of Saharan data from Moreno et al. (2006). In contrast, the ratio between particulate $\mathrm{Al}$ and $\mathrm{Si}$ (or $\mathrm{Ti}$ ) levels is 2 to 4 times higher than that in Moreno et al. (2006), indicating a Si (Ti) deficit, by comparison with other major Saharan soil elements (for clarification, see Fig. S3 in the Supplement). After aerosol measurements performed in southern Morocco, Kandler et al. (2009) concluded that the major dust constituents were quartz, potassium feldspar, plagioclase, calcite, hematite and clay minerals. Particles in the range of $0.5-50 \mu \mathrm{m}$ consisted mainly of silicates and, above $50 \mu \mathrm{m}$, quartz was dominant.

Published information concerning the $\mathrm{Al} / \mathrm{Si}$ mass ratios in atmospheric dust from the Saharan region is still scarce. $\mathrm{Al} / \mathrm{Si}$ average ratios of $0.43-0.49$, with values, depending on the air mass origin, were measured by Chiapello et al. (1997), using bulk filtration, on Sal island, Cabo Verde. Formenti et al. (2003) determined $\mathrm{Al} / \mathrm{Si}$ ratios of the order of 0.5 , in particles larger than $1 \mu \mathrm{m}$, during aircraft measurements performed in the Cabo Verde region. Remoundaki et al. (2013) found $\mathrm{Al} / \mathrm{Si}$ ratios of $0.44 \pm 0.12$ in $\mathrm{PM}_{2.5}$ aerosols collected in Greece under the influence of air mass transport from the Saharan region. In South America, Formenti et al. (2001) observed $\mathrm{Al} / \mathrm{Si}$ values of $0.48 \pm 0.08$ in fine particles and of $0.77 \pm 0.18$ in the coarse aerosol fraction. Aerosol measurements over the western Atlantic and the eastern coast of the US present an $\mathrm{Al} / \mathrm{Si}$ ratio value coincident with our measurements (Eldred, 2003). From this information, we hypothesise that during long-range transport of Saharan dust there is a prevalent loss, by sedimentation (or non-emission), of $\mathrm{Si}$ (and Ti), in comparison to other particulate dust components, which becomes more evident for larger particles.

Because of the $\mathrm{Al} / \mathrm{Si}$ behaviour in our samples, we felt more confident in using $\mathrm{Fe}$ as a representative tracer of soil contribution in composition/mass balance calculations. In addition, $\mathrm{Fe}$ is the soil element that showed a better correlation $(R=0.99)$ with $\mathrm{PM}_{10}$ total mass during dust events (see Fig. S4 in the Supplement for visualisation).

In coastal, or marine, non-dusty environments, it is common, and correct, to infer the mass contribution of particulate sea spray to the atmospheric aerosol by using $\mathrm{Mg}^{2+}$ or, predominantly, $\mathrm{Na}^{+}$, as an exclusive sea-salt tracer. However, these ions are also present in the soil and, during dust episodes, the soil contribution cannot be neglected. From Fig. 1 it is possible to observe that sea-salt concentrations calculated in this way increase steeply during dust pollution episodes, which is not reasonable. 
To eliminate the soil interference in sea-salt estimation, we employed $\mathrm{Fe} / \mathrm{Mg}^{2+}$ and $\mathrm{Fe} / \mathrm{Na}^{+}$mass ratio superior edge lines (see Fig. 2). Similarly to Pio et al. (2011), edge lines' estimation is based on tracing a linear best-fit line through the $5 \%$ of total concentration points (seven points in our case) with the highest $\left(\mathrm{Fe} /\left(X-X_{\min }\right)\right.$ ratios, where, presently, $X$ is $\mathrm{Na}^{+}$or $\mathrm{Mg}^{2+}$ ion concentration and $X_{\min }$ is the respective measured minimum ion concentration. These edge lines represent the minimum fractional contribution of sea salt to $\mathrm{Na}^{+}$and $\mathrm{Mg}^{2+}$ in the aerosol, compatible with experimental data. Therefore, it is expectable that they represent, reasonably well, the ratios between the ions and Fe, in soil dust, as long as it is acceptable that, in such a location, these are the unique major sources of $\mathrm{Fe}$ and $\mathrm{Na}^{+}$. Based on these edge line ratios, the amounts of soil $\mathrm{Mg}^{2+}$ and $\mathrm{Na}^{+}$ions can thus be determined and subtracted from the total ion concentrations, permitting a first estimation of sea-salt $\mathrm{Mg}_{\mathrm{s}}^{2+}$ and $\mathrm{Na}_{\mathrm{s}}^{+}$. As these edge lines only approximatively represent the soil ratios, the calculation of sea-salt contributions may consequently suffer from these inaccuracies/variabilities.

A further refinement of sea-salt calculation can be implemented by looking at the ratios $\left(\mathrm{Na}_{\mathrm{s}}^{+} / \mathrm{Mg}_{\mathrm{s}}^{2+}\right)$ calculated from $\mathrm{Na}_{\mathrm{s}}^{+}$and $\mathrm{Mg}_{\mathrm{s}}^{2+}$ in each sample and comparing them with those in seawater $\left(\mathrm{Mg}_{\mathrm{ss}}^{2+} / \mathrm{Na}_{\mathrm{ss}}^{+}=0.12 \mu \mathrm{g} \mu \mathrm{g}^{-1}\right.$, Turekian, 1968). Since it is not possible to have less $\mathrm{Mg}_{\mathrm{ss}}^{2+}$ (or more $\mathrm{Na}_{\mathrm{ss}}^{+}$) ion mass sea salt than the one given by the 0.12 ratio, if $\mathrm{Mg}_{\mathrm{s}}^{2+} / \mathrm{Na}_{\mathrm{s}}^{+} \geq 0.12, \mathrm{Na}_{\mathrm{s}}^{+}$is chosen as the true sea salt $\mathrm{Na}_{\mathrm{ss}}^{+}$concentration. Otherwise, $\mathrm{Mg}_{\mathrm{s}}^{2+}$ is chosen as the true $\mathrm{Mg}_{\mathrm{ss}}^{2+}$ tracer. The contributions of other sea-salt ions are, consequently, estimated from the chosen $\mathrm{Na}_{\mathrm{ss}}^{+}$or $\mathrm{Mg}_{\mathrm{ss}}^{2+}$, using the salt ratios present in seawater (Turekian, 1968).

Figure 1 presents the estimation of sea-salt contribution to the aerosol (Sea-salt recalc), considering the methodology described above. The figure shows that, with the modified methodology, there is no increase of sea-salt aerosol loading during dust intrusions, in contrast with the standard methodology. During the dust periods there is even a decrease in the contribution of sea salt to the aerosol that may result either from excessive calculation of soil $\mathrm{Na}^{+}$and $\mathrm{Mg}^{2+}$ or, more probably, from an increased deposition rate of sea salt during dusty periods, by co-sedimentation of dust and sea-salt particles. Because of the application of our adapted alternative methodology, the amount of calculated sea-salt contribution decreases by $47 \%$ in the dry-haze season and $32 \%$ in the rest of the year.

The correct determination of sea-salt ion concentrations permits the estimation of the remaining common elements, supposedly from soil origin. In this way, it is possible to calculate $\mathrm{Mg}_{\text {soil }}, \mathrm{K}_{\text {soil }}$ and $\mathrm{Ca}_{\text {soil }}$ concentrations. Determination of total $\mathrm{Na}_{\text {soil }}$ and $\mathrm{Cl}_{\text {soil }}$ is not feasible in this work because of analytical limitations.

Taking into account that we did not, or could not, measure with accuracy $\mathrm{P}$ and $\mathrm{Na}$, the calculation of soil contribution was done by adapting Eq. (2) to

$$
\begin{aligned}
\text { Soil dust }= & 1.15(2.14 \mathrm{Si}+1.89 \mathrm{Al}+1.43 \mathrm{Fe}+1.39 \mathrm{Mn} \\
& +1.67 \mathrm{Ti}+1.66 \mathrm{Mg}_{\text {soil }}+1.40 \mathrm{Ca}_{\text {soil }} \\
& \left.+1.20 \mathrm{~K}_{\text {soil }}\right),
\end{aligned}
$$

where the factor 1.15 is an average for the nine sites studied by Moreno et al. (2006) (see Table S1 in the Supplement for details and clarification). This factor is higher than the corresponding values for the average continental/upper crust (1.05-1.06), taken from Mason and Moore (1982) and Wedepohl (1995).

\subsection{Secondary formation processes}

The attribution of analysed water-soluble anions and cations to different sources and formation processes can be done using the sequential ionic balance proposed by Alastuey et al. (2005), adapted and developed by Mirante et al. (2014) for Madrid urban aerosol. The present situation, with very large inputs of dust and marine aerosols, imposes a further adaptation of the ionic balance method, because gas-to-particle reactions involving precursor pollutants and sea-salt spray, or dust, cannot be neglected, and from the evaluation of dust and sea-salt composition, the amounts of soluble ions of seasalt and dust origin have to be initially calculated. Therefore, the ionic balance applied to the present samples is the following:

1. Start by calculating soil $\mathrm{Na}_{\text {soil }}^{+}$and soil $\mathrm{Mg}_{\text {soil }}^{2+}$ from $\mathrm{Fe} / \mathrm{Na}^{+}$and $\mathrm{Fe} / \mathrm{Mg}^{2+}$ edge lines in Fig. 2.

2. Calculate sea-salt $\mathrm{Na}_{\mathrm{s}}^{+}$and $\mathrm{Mg}_{\mathrm{s}}^{2+}$ from differences between total and soil $\mathrm{Na}_{\text {soil }}^{+}$and $\mathrm{Mg}_{\text {soil }}^{2+}$.

3. Recalculate sea-salt $\mathrm{Na}_{\mathrm{ss}}^{+}$and $\mathrm{Mg}_{\mathrm{ss}}^{2+}$ using minimum values and the $\mathrm{Na}^{+} / \mathrm{Mg}^{2+}$ ratio in seawater.

4. Calculate sea-salt mass concentration and composition from $\mathrm{Na}_{\mathrm{ss}}^{+}$and $\mathrm{Mg}_{\mathrm{ss}}^{2+}$, and seawater ion ratios, taking into account available $\mathrm{Cl}^{-}$.

5. Calculate non-sea-salt $\mathrm{SO}_{4}^{2-}, \mathrm{NO}_{3}^{-}$and $\mathrm{Cl}^{-}$.

6. Associate, sequentially, free non-sea-salt $\mathrm{SO}_{4}^{2-}$ and $\mathrm{NO}_{3}^{-}$with $\mathrm{NH}_{4}^{+}$, until all $\mathrm{NH}_{4}^{+}$is neutralised.

7. From the differences between total and sea-salt cations, calculate soil $\mathrm{Na}_{\text {soil }}^{+}, \mathrm{Mg}_{\text {soil }}^{2+}, \mathrm{K}_{\text {soil }}^{+}$and $\mathrm{Ca}_{\text {soil }}^{2+}$.

8. Associate free $\mathrm{NO}_{3}^{-}$, sequentially, with free sea-salt and soil cations.

9. Associate, totally, $\mathrm{CO}_{3}^{2-}$, sequentially, with free soil $\mathrm{Ca}_{\text {soil }}^{2+}, \mathrm{Mg}_{\text {soil }}^{2+}, \mathrm{Na}_{\text {soil }}^{+}$and $\mathrm{K}_{\text {soil }}^{+}$.

10. Associate free $\mathrm{SO}_{4}^{2-}$, sequentially, with free $\mathrm{Ca}_{\text {soil }}^{2+}$, $\mathrm{Mg}_{\text {soil }}^{2+}, \mathrm{Na}_{\text {soil }}^{+}$and $\mathrm{K}_{\text {soil }}^{+}$. 

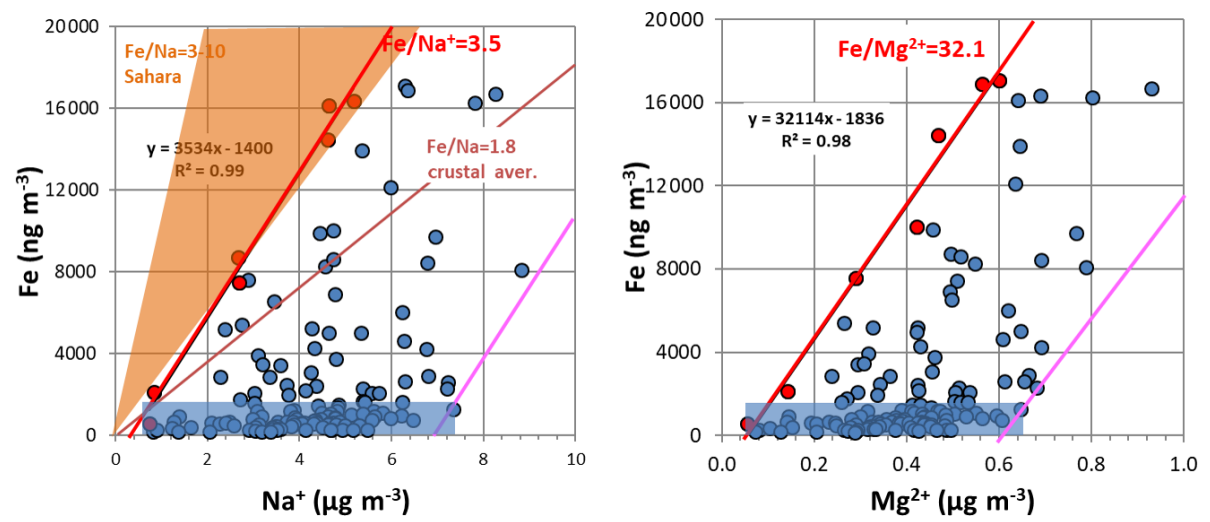

Figure 2. Edge lines (in red) for $\mathrm{Fe}$ versus $\mathrm{Na}^{+}$and $\mathrm{Fe}$ versus $\mathrm{Mg}^{2+}$ intercomparisons. The blue rectangle represents periods without significant dust intrusions. The pink lines are parallels to the red edge lines in the maximum ion concentration regions. Also shown are $\mathrm{Fe} / \mathrm{Na}$ ratio ranges in Sahara and global soils, for total sodium, taken from Moreno et al. (2006) and Mason and Moore (1982). Edge lines are best-fit linear lines traced through points in red.

11. Associate free $\mathrm{Cl}^{-}$with free $\mathrm{Na}_{\text {soil }}^{+}$and $\mathrm{Mg}_{\text {soil }}^{2+}$. Any excess $\mathrm{Cl}^{-}$is associated with $\mathrm{K}_{\text {soil }}^{+}$.

12. Calculate the total masses of water-soluble soil sulfate, nitrate and chloride.

13. Edge line ratios between $\mathrm{Fe}$ and sulfate, nitrate, or chloride permit a rough calculation of the fraction of these ionic compounds that is present in the soil or that results from secondary reaction with atmospheric produced acids (for visualisation, see Fig. S5 in the Supplement).

Using an Excel spreadsheet, the 13 steps were applied, sequentially, in order to attribute all measured cations and anions to sea salt, soil and secondary inorganic compounds. The first four steps were described in detail in the beginning of this section. Due to space limitations, only results for the remaining eight steps are presented.

Using a OM/OC ratio of 2.0 and measured EC and OC, it is also possible to estimate the total non-carbonated, carbonaceous aerosol.

With this IMB methodology, it is possible to account for the presence of seven source classes: sea-salt spray (SeaSalt), insoluble soil dust (SoilDust ins), soluble soil dust (SoilDust sol), secondary inorganic compounds from the reaction of atmospheric acids with ammonia (SIC am), sea salt (SIC ss) and dust (SIC du), and non-carbonate carbonaceous elemental and organic matter (Carbon).

The results of water-soluble compounds are presented in Table 2 for the dry-haze and dust-free seasons. Concentrations of secondary ammonium salts (SIC am) are more than doubled during the dust-free season, probably as a result of higher temperatures and transport of air masses from nondesert polluted areas, or the removal by co-sedimentation with dust during dust episodes. Soluble soil dust (SoilDust sol) are more than tripled during the dry-haze season, being formed mainly by calcium carbonates and sulfates, sodium nitrates and sulfates, and by sodium chloride.

Reaction of acid precursors with soil dust (SIC du) produces equivalent amounts of secondary compounds during the two seasons, probably because of limited availability of acidic precursors. Secondary processes resulting from acidic reactions with sea salt (SIC ss) produce more sea-salt secondary material during the dust-free season. As, in the present conditions, it is difficult to clearly differentiate between the two processes, because it is not possible to give a priority in the competitive acidic reaction with sea salt or dust; in the rest of the publication, the two source processes are treated together, as SIC ss+du.

\subsection{Particulate water}

The fractional contribution of the six adapted source classes is given in Fig. 3 for the two seasons and for the total campaign. The figure reveals that the sum of the quantified sources only accounts for $76 \%$ of the measured $\mathrm{PM}_{10}$ total mass concentration, on average, during the total measurement campaign. The value decreases to $68 \%$ during the dustfree season. These fractions are of the same order of values published in literature (Perrino et al., 2013; Rees et al., 2004; Andrews et al., 2000; Grigoratos et al., 2014).

As, in our case, carbonates were directly measured, it is predictable that most of the unaccounted mass results from the aerosol water content, in the form of adsorbed/absorbed water (hydrates in soil constituents were already considered with the application of factor $F$ ), now that $\mathrm{PM}_{10}$ total mass measurement was performed at $20^{\circ} \mathrm{C}$ and $50 \% \mathrm{RH}$, in conditions of equilibrium between the laboratory atmospheric water vapour and the particulate material in the filter.

To estimate the amount of sorbed water in the aerosol, we consider that, by approximation, there is a thermodynamic equilibrium between the controlled room atmosphere, 
Table 2. Soil and secondary inorganic compounds resulting from the ionic balance.

\begin{tabular}{|c|c|c|c|c|c|c|c|c|}
\hline \multirow{3}{*}{ Inorganic compounds } & \multirow{2}{*}{\multicolumn{2}{|c|}{ SIC am }} & \multirow{2}{*}{\multicolumn{2}{|c|}{ SoilDust sol }} & \multicolumn{4}{|c|}{ SIC ss+du } \\
\hline & & & & & \multicolumn{2}{|c|}{ SIC du } & \multicolumn{2}{|c|}{ SIC ss } \\
\hline & $\begin{array}{l}\text { Dust-free } \\
\left(\mu \mathrm{g} \mathrm{m}^{-3}\right)\end{array}$ & $\begin{array}{l}\text { Dry haze } \\
\left(\mu \mathrm{g} \mathrm{m}^{-3}\right)\end{array}$ & $\begin{array}{l}\text { Dust-free } \\
\left(\mu \mathrm{g} \mathrm{m}^{-3}\right)\end{array}$ & $\begin{array}{l}\text { Dry haze } \\
\left(\mu \mathrm{g} \mathrm{m}^{-3}\right)\end{array}$ & $\begin{array}{l}\text { Dust-free } \\
\left(\mu \mathrm{g} \mathrm{m}^{-3}\right)\end{array}$ & $\begin{array}{l}\text { Dry haze } \\
\left(\mu \mathrm{g} \mathrm{m}^{-3}\right)\end{array}$ & $\begin{array}{l}\text { Dust-free } \\
\left(\mu \mathrm{g} \mathrm{m}^{-3}\right)\end{array}$ & $\begin{array}{l}\text { Dry haze } \\
\left(\mu \mathrm{g} \mathrm{m}^{-3}\right)\end{array}$ \\
\hline$(\mathrm{NH} 4)_{2} \mathrm{SO}_{4}$ & 0.94 & 0.37 & & & & & & \\
\hline $\mathrm{NH}_{4} \mathrm{NO}_{3}$ & 0.00 & 0.01 & & & & & & \\
\hline $\mathrm{CaCO}_{3}$ & & & 0.27 & 3.15 & & & & \\
\hline $\mathrm{MgCO}_{3}$ & & & 0.01 & 0.25 & & & & \\
\hline $\mathrm{Na}_{2} \mathrm{CO}_{3}$ & & & 0.00 & 0.28 & & & & \\
\hline $\mathrm{K}_{2} \mathrm{CO}_{3}$ & & & 0.00 & 0.00 & & & & \\
\hline $\mathrm{NaNO}_{3}$ & & & 0.86 & 1.26 & 0.79 & 0.83 & 0.43 & 0.16 \\
\hline $\mathrm{Mg}\left(\mathrm{NO}_{3}\right)_{2}$ & & & 0.10 & 0.12 & 0.09 & 0.08 & 0.08 & 0.03 \\
\hline $\mathrm{KNO}_{3}$ & & & 0.06 & 0.10 & 0.05 & 0.06 & 0.01 & 0.00 \\
\hline $\mathrm{Ca}\left(\mathrm{NO}_{3}\right)_{2}$ & & & 0.01 & 0.00 & 0.00 & 0.00 & 0.02 & 0.01 \\
\hline $\mathrm{CaSO}_{4}$ & & & 0.59 & 0.43 & 0.52 & 0.28 & & \\
\hline $\mathrm{MgSO}_{4}$ & & & 0.01 & 0.15 & 0.01 & 0.09 & & \\
\hline $\mathrm{Na}_{2} \mathrm{SO}_{4}$ & & & 0.12 & 0.80 & 0.11 & 0.52 & & \\
\hline $\mathrm{K}_{2} \mathrm{SO}_{4}$ & & & 0.05 & 0.06 & 0.05 & 0.04 & & \\
\hline $\mathrm{NaCl}$ & & & 0.27 & 1.75 & 0.13 & 0.29 & & \\
\hline $\mathrm{MgCl}_{2}$ & & & 0.00 & 0.06 & 0.00 & 0.01 & & \\
\hline $\mathrm{KCl}$ & & & 0.00 & 0.06 & 0.00 & 0.01 & & \\
\hline Total & 0.94 & 0.37 & 2.34 & 8.48 & 1.74 & 2.21 & 0.54 & 0.20 \\
\hline
\end{tabular}
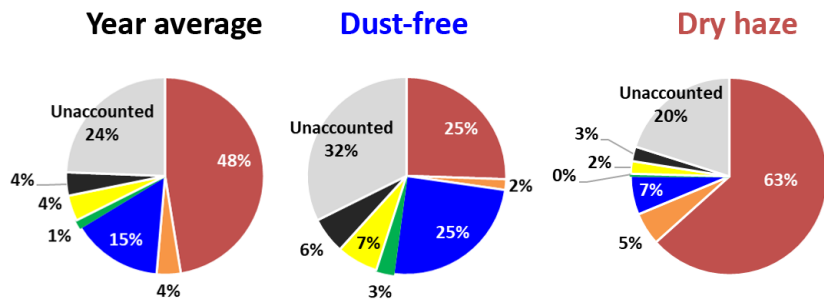

- SoilDust ins $=$ SoilDust sol - SeaSalt $\|$ SIC am $=$ SIC ss+du - Carbon = Unaccounted

Figure 3. Contribution of different components to the $\mathrm{PM}_{10}$ measured total mass, estimated by IMB, for the whole sampling campaign and for the dust-free and dry-haze seasons.

at $20^{\circ} \mathrm{C}$ and $50 \% \mathrm{RH}$, and the aerosol deposited on the filter, during the mass weighting in the laboratory, and also that the behaviour of different compounds is independent of internal or external mixture conditions.

For sea salt, thermodynamic information from Tang et al. (1997) was used, which, at $50 \% \mathrm{RH}$ and $20^{\circ} \mathrm{C}$, indicates a water/salt mass equilibrium ratio of 0.4 for a dry phase state, or 1.4 for a metastable deliquescent liquid phase state. The ISORROPIA thermodynamic equilibrium model (Nenes et al., 1998a, b) was applied, at $20^{\circ} \mathrm{C}$ and $50 \% \mathrm{RH}$, both to the calculated sea salt alone (SeaSalt) and considering together the sea salt and the secondary inorganic compound formation by the attack of atmospheric acids (SeaSalt + SIC ss). ISOR-
ROPIA output gave water fractions that were very similar, in both cases, and also coincident with the values taken from Tang et al. (1997) for wet or dry containing phases. As information about phase status during weighting is unavailable and the weighting was performed at RH very near the forced efflorescence point $(47 \% \mathrm{RH})$, we used for the water/salt ratio the arithmetic average of the two equilibrium values $(0.9)$.

For secondary inorganic water-soluble ammonium salts (mainly ammonium sulfate), thermodynamic information from Xu et al. (1998) and Tang and Munkelvitz (1994) was applied, which shows an equilibrium water/ammonium sulfate mass ratio of 0.4 at $50 \% \mathrm{RH}$.

The information concerning the water content of organic polar matter was taken from Speer et al. (2003) who used a water/OC ratio of 0.2 .

Suspended soil also sorbs water, principally the watersoluble ionic component. We used ISORROPIA, version 2.1, which includes ions from crustal origin, to estimate the water content in soluble dust. The ISORROPIA II version was run for a liquid metastable assumption and applied to the soluble soil dust (SoilDust sol) and to the sum of soluble soil dust and secondary inorganic compounds formed from the attack of atmospheric acids on dust particles (SoilDust sol + SIC $\mathrm{du}$ ). In the first case, the average water/salt mass ratio calculated was 0.22 in the dust-free season and 0.47 in the dry-haze season. In the mixture, the calculated ratios were 

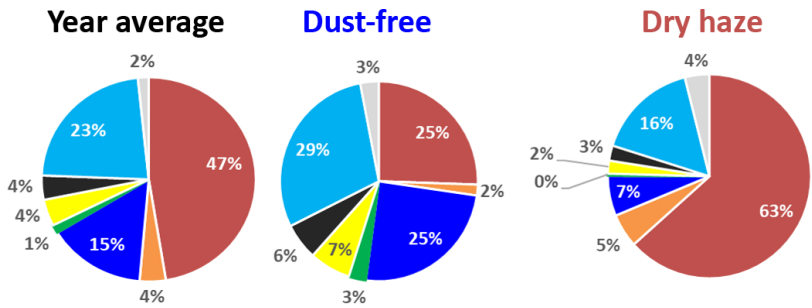

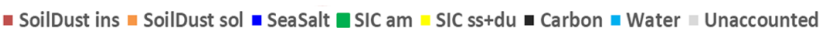

Figure 4. Inclusion of estimated water in the IMB for the total sampling campaign and for the dust-free and dry-haze seasons.

comparable ( 0.14 and 0.50 , respectively). Due to the lack of more specific information, water/soluble dust ratio values of 0.2 , during the dust-free season, and 0.5 during the rest of the year, were employed.

Various important components of the insoluble fraction of dust are hygroscopic, such as clay minerals. Schuttlefield et al. (2007) measured water adsorption by clay minerals having found a large variability in the water uptake by different clay mineral species, with water/clay mass ratios varying from 0.02 to 0.06 for kaolinite, going up to 0.17 for illite and $0.08-0.7$ for montmorillonite, at $23^{\circ} \mathrm{C}$ and $50 \% \mathrm{RH}$. Based on these data, a round value of 0.1 for the ratio of water/SoilDust ins was adopted for our samples.

The estimation of total water content in the collected aerosols using the above referred ratio assumptions is presented in Fig. 4. The figure shows that, by using this methodology, there is almost a perfect account of the $\mathrm{PM}_{10}$ total mass. Water represents an average contribution of $23 \%$ to the aerosol mass. During the dry-haze period, the calculated water, on average, accounts for $16 \%$ of the $\mathrm{PM}_{10}$ mass, with a maximum contribution of $29 \%$ during the dust-free season. By including particulate water, only around $2 \%-4 \%$ of the PM total mass is unaccounted, with the applied IMB methodology.

\subsection{Comparison with PMF}

The final ionic and mass balance calculations are presented in Fig. 5 for the total campaign and the two seasons, considering the components associated with the respective water uptake. The addition of sorbed water reinforces the impact of hygroscopic/soluble components, such as sea salt, in the atmospheric aerosol loading, which, for example, during the dust-free season increases its contribution from $25 \%$ to $47 \%$.

The results of IMB can be evaluated and compared with PMF results applied to the same data set and already published by Salvador et al. (2016). Here, the published PMF results were reorganised, in order to make explicit the PMF contributions during the two dry-haze and dust-free seasons and to show unaccounted/excess calculated PM mass, as represented in Fig. 6.
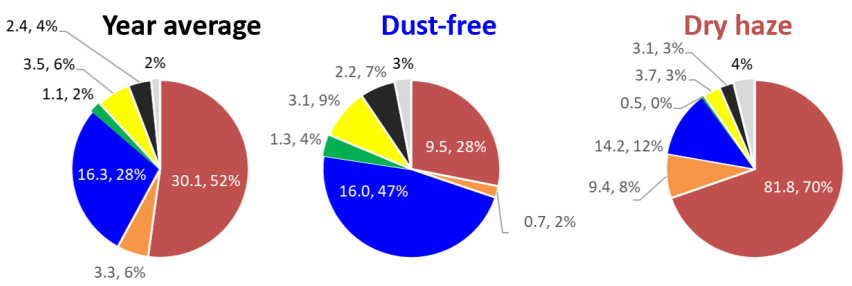

- WetSoilDust ins $=$ WetSoilDust sol - WetSeaSalt $\mid$ WetSIC am "WetSIC ss+du - WetCarbon " Unaccounted

Figure 5. IMB obtained by attributing the calculated water content to the respective source classes for the entire campaign and the dustfree and dry-haze seasons. Values are in $\mu \mathrm{g} \mathrm{m}^{-3}$ and percentage of measured total mass.
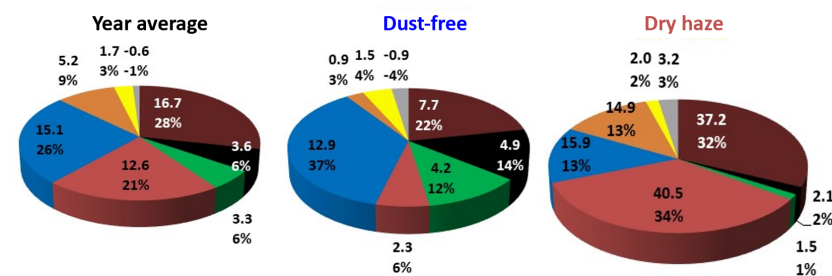

- Dust+Ind - Combustion $\quad \|$ SIC1

m Mineral1

neaSalt

= Mineral2 $=$ SIC2 $=$ Unaccounted

Figure 6. PMF source apportionment results for the total campaign and during the two pollution seasons. Values are in $\mu \mathrm{g} \mathrm{m}^{-3}$ and percentage of measured total mass.

The PMF analysis could differentiate seven aerosol sources: three concerning soil contamination and two considering secondary inorganic components, plus sea-salt and combustion processes. The dust sources comprised "Mineral1", associated mainly with $\mathrm{Al}, \mathrm{Si}$ and $\mathrm{Fe}$; "Mineral2", associated with $\mathrm{CO}_{3}^{2-}$ and $\mathrm{Ca}^{2+}$; and "Dust+Ind", containing both soil elements ( $\mathrm{Al}, \mathrm{Si}, \mathrm{Fe})$ and tracers of industrial emissions $(\mathrm{V}, \mathrm{Ni}, \mathrm{Cu}$ and $\mathrm{Cr})$. The secondary inorganic components included "SIC1", associated with $\mathrm{NH}_{4}^{+}, \mathrm{SO}_{4}^{2-}$, $\mathrm{NO}_{3}^{-} \mathrm{Na}^{+}, \mathrm{K}^{+}$and $\mathrm{Mg}^{2+}$; and "SIC2", containing $\mathrm{SO}_{4}^{2-}$, $\mathrm{NO}_{3}^{-}, \mathrm{Ca}^{2+}$ and $\mathrm{Mg}^{2+}$. The "SeaSalt" source represented most of the variability of $\mathrm{Na}^{+}, \mathrm{Cl}^{-}, \mathrm{Mg}^{2+}, \mathrm{Br}$ and $\mathrm{K}^{+}$. The "Combustion" source included mainly EC and OC variability (complementary information concerning PMF sources compositions and contributions can be found in Fig. S8 in the Supplement).

Figures 5-6 and Table 3 compare both methodologies for the two seasons and the total campaign (for individual sampling events, consult Figs. S6 and S7 in the Supplement). There is a good agreement between the two source apportionment techniques. Both methodologies reproduce almost totally the measured $\mathrm{PM}_{10}$ total mass.

The figures and table show a good comparability between total soil dust estimated by both methods in any season. In the IMB, the SoilDust sol fraction is approximately equivalent to the Mineral 2 component of PMF. The mass balance method could not discriminate the Dust + Ind from the total insoluble dust fraction, as was possible with PMF. 
Table 3. Comparison between IMB and PMF results, grouped into four main classes. $\mathrm{PM}_{10}$ represents gravimetric measurements of total mass (in IMB: Soil is the total of WetSoilDust ins plus WetSoilDust sol, SIC is the total of WetSIC am plus WetSIC ss+du; in PMF: SIC is the total of SIC1+SIC2, Soil is the total of Mineral1 plus Mineral2 plus Dust+Ind).

\begin{tabular}{lrr|rr|rr}
\hline & \multicolumn{2}{c|}{ Year average } & \multicolumn{2}{c|}{ Dry haze } & \multicolumn{2}{c}{ Dust-free } \\
\cline { 2 - 7 } & $\begin{array}{r}\text { PMF } \\
\left(\mu \mathrm{g} \mathrm{m}^{-3}\right)\end{array}$ & $\begin{array}{r}\mathrm{IMB} \\
\left(\mu \mathrm{g} \mathrm{m}^{-3}\right)\end{array}$ & $\begin{array}{r}\text { PMF } \\
\left(\mu \mathrm{g} \mathrm{m}^{-3}\right)\end{array}$ & $\begin{array}{r}\mathrm{IMB} \\
\left(\mu \mathrm{g} \mathrm{m}^{-3}\right)\end{array}$ & $\begin{array}{r}\text { PMF } \\
\left(\mu \mathrm{g} \mathrm{m}^{-3}\right)\end{array}$ & $\begin{array}{r}\text { IMB } \\
\left(\mu \mathrm{g} \mathrm{m}^{-3}\right)\end{array}$ \\
\hline Soil & 34.5 & 33.5 & 92.6 & 91.2 & 10.9 & 10.2 \\
Sea salt & 15.1 & 16.3 & 15.9 & 14.2 & 12.9 & 16.0 \\
SIC & 4.9 & 4.6 & 3.5 & 4.2 & 5.7 & 4.4 \\
Carbon/Combust & 3.6 & 2.4 & 2.1 & 3.1 & 4.9 & 2.2 \\
\hline Sum & 58.2 & 56.8 & 114.1 & 112.7 & 34.5 & 32.8 \\
\hline PM $_{10}$ & 57.7 & & 117.3 & & 33.9 \\
\hline
\end{tabular}

Contribution of sea salt was also equally estimated by the two techniques, on average, during the dry-haze season, but during the dust-free period the IMB estimated somehow higher sea-salt levels than the PMF.

SIC values are similar in both source apportionment methodologies, but during the dust-free period PMF estimated higher SIC contributions. This was mainly due to higher estimations of ammonium secondary salts by PMF, which only can happen if other compounds are included in the source component, as evidenced by the PMF source profile.

There is also a higher contribution from carbonaceous/organic/combustion material in PMF, by comparison with IMB, during the dry season, although a high factor of 2 was applied to the OM/OC ratio in the mass balance approach. The inclusion by the PMF of other constituents from combustion processes in west Africa is, probably, the reason for the discrepancy.

Further insight into the capabilities and limitations of IMB versus PMF can be attained by comparing source classes for each individual sample, as presented in Fig. 7. From this figure it is possible to confirm the good comparability between the soil source estimations by both methods, with a linear ratio estimation of 1.04 and a correlation $R=0.97$.

For sea-salt estimation, the comparison is not so good with IMB/PMF ratio estimation of only 0.68 and an $R=0.82$. This happens principally because, for several samples, PMF gives zero or negative sea-salt contributions, while the IMB estimates important sea-salt values. For a location in the middle of the ocean, it is not expectable to have absence of sea salt, and therefore, in our opinion, PMF fails, attributing, probably, the available sea salt to a soil source. At high concentration levels, there is a tendency of PMF to give higher sea-salt values than IMB. An inspection of PMF compounds' contribution to the sea-salt source shows that, on average, there is a mass inclusion of about $20 \%$ of elements such as $\mathrm{Si}, \mathrm{Al}, \mathrm{Fe}$, etc. in this source (see Fig. S8, graph 8, for clarification). Therefore, it is clear that PMF could not completely separate soil from sea-salt sources, probably because of the overwhelming presence of soil during dust episodes. During the dust-free season, IMB tends to give somehow higher seasalt contributions than PMF (sea-salt IMB is 0.73 sea-salt PMF plus $6.8 ; R=0.84$ ). One of the possible reasons may be a too-high estimation of sea-salt sorbed water in IMB.

Both methodologies also compare reasonably well in what concerns secondary inorganic compounds (SICs) contributions to the aerosol loading, with a IMB/PMF ratio of 0.83 and a correlation coefficient $R=0.77$. Where the comparison fails completely is in the carbonaceous (IMB) versus combustion (PMF) sources that present no clear relation. This results from several facts as exposed in the following text. The IMB source profile represents only non-carbonate carbonaceous matter, irrespective of the source, while the PMF factor intends to represent all emissions from combustion sources, besides carbonaceous matter. Therefore, from Fig. 7, it is possible to observe in several samples important contributions of carbonaceous matter estimated by IMB, while PMF gives zero to negative combustion emission estimations. Most probably this results from soil contribution to organic matter that in PMF is attributed to dust or anthropogenic sources (Ant + Dust; see graphs $\mathrm{C}$ and $\mathrm{H}$ in Fig. S8 for clarification). Also, in PMF, the combustion source has, on average, an important contribution (around 50\%; see Fig. S8 for clarification) of elements, such as Si, Al, Fe, etc., from soil origin; therefore, in our opinion, this PMF combustion source is highly contaminated with soil, with PMF not fully capable of separating combustion from soil dust, due to the overwhelming presence of soil particles during dust episodes.

From Table 3 and Fig. 7 we may then conclude that the IMB solution compares well with PMF for dust and SIC, but the two methods show important discrepancies for individual samples, principally in the estimation of sea salt and carbonaceous aerosol contributions. 

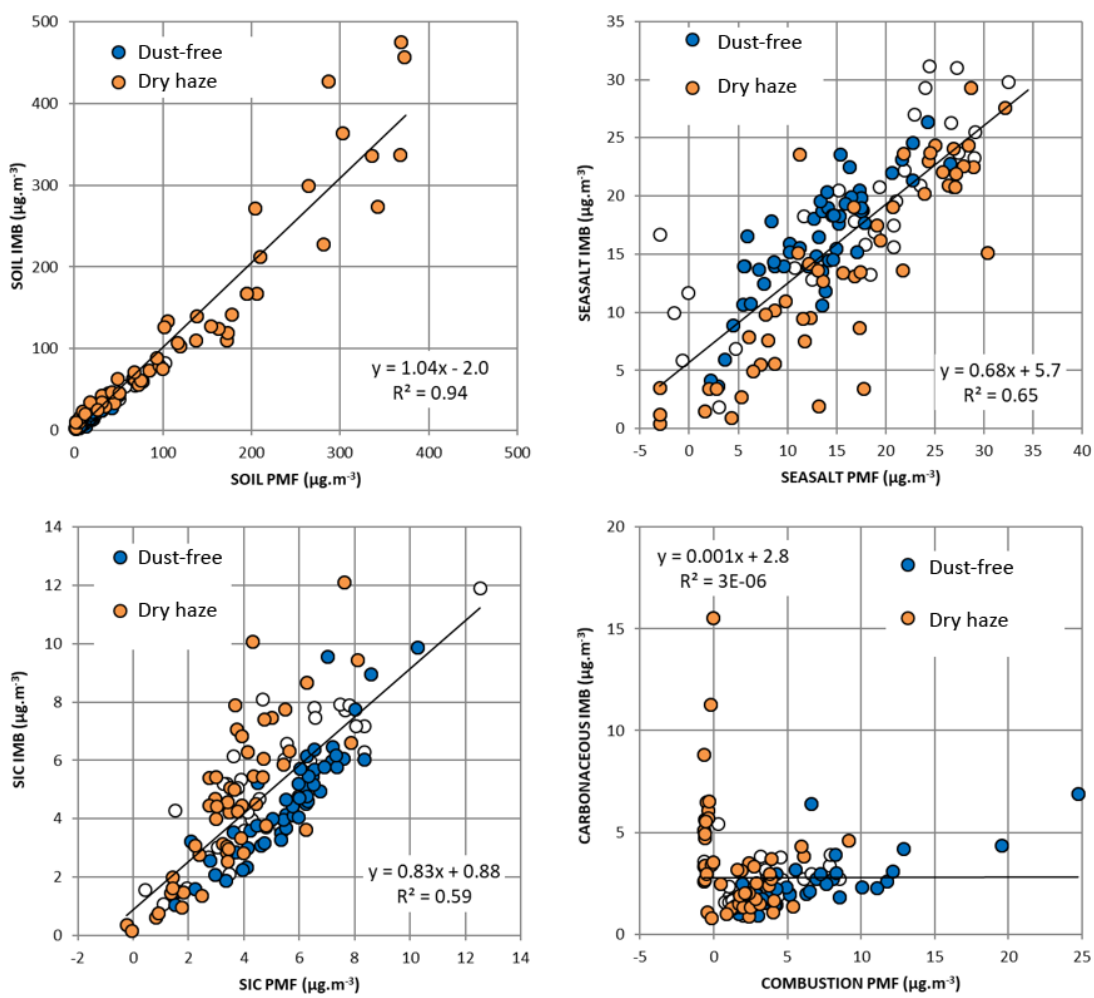

Figure 7. Comparison between the apportionment of individual samples using IMB and PMF for four source classes. Circles filled in white represent periods with intermittent dust intrusions. Linear best fits are presented for the total sampling campaign.

\subsection{Accuracy and errors}

IMB and PMF are subject to a number of errors that affect the precision and accuracy of the sources' estimation. Fully accounting for all errors is difficult, because some used information (bibliographic or experimental) has no available accuracy or is subject to unknown and unexpected errors. PMF applies several statistical tests to evaluate the influence of random errors and the rotational ambiguity of the obtained solution. Although these tests indicated that the PMF solution was robust, they could not identify collinearity problems that resulted in the significant contamination of combustion and sea-salt sources with soil dust.

Both methodologies are equally affected by errors in the aerosol chemical analysis. Probably the higher relative analytical errors are related with elements and EC evaluation, in conditions of high dust concentrations, although care was taken to sample for shorter periods during dust episodes. EC is frequently near the detection limits and it is quite difficult to fully evaluate the interference of coloured dust during the thermo-optical analytical process. This affects, in an unknown value, principally, the evaluation of the PMF combustion source that uses EC as its principal tracer (see Fig. S8 for clarification).

In IMB, there are probably four estimations where the errors influencing the source apportionment are higher: (a) cal- culation of water sorbed in sea salt; (b) the estimation of total soil content based in factor $F$; (c) calculation of sea-salt $\mathrm{Na}^{+}$; (d) the estimation of organic matter from OC. It is necessary to take into account, however, that total errors are controlled by measured $\mathrm{PM}_{10}$ total mass constraint (Malm et al., 1994 use this comparison as a validation and self-consistency check for their reconstructed aerosol mass balance). Being the sum of estimated masses within $96 \%-98 \%$ of measured $\mathrm{PM}_{10}$ total mass, the individual errors are probably limited (or of opposite directions, with mutual compensation).

Estimation of water content in sea salt depends mainly on metastable equilibrium considerations that give a water/dry sea-salt mass ratio varying from 0.4 to 1.4 . An average value of 0.9 was applied in our calculations. Application of the two extreme values would vary the fractional contribution of wet sea salt by approximately $\pm 6 \%, \pm 7 \%$ or $\pm 3 \%$ for the total sampling campaign, the dust-free or the dry-haze periods. It is necessary to consider, however, that by choosing the two ratio extremes the closure of the total PM mass would be affected, resulting in a maximum unaccounted mass of $16 \%$ for the choice of a 0.4 value, and a maximum overprediction of $8 \%$ for the choice of 1.4 ratio, and therefore the correctness of these extreme values is questionable.

The calculation of the total soil dust was based on Eq. (3) that uses an average factor $F$ value of 1.15. $F$ values taken from Moreno et al. (2006) (see Table S1 in the Supplement, 
for clarification) vary in the range 1.09-1.27 (standard deviation of 0.21 ) and the factor $F$ for global composition is $1.05-1.06$. A range of approximately $16 \%$ will result from the calculation of soil dust contribution by application of the two extreme $F$ factors. Use of extreme $F$ values would give a maximum unaccounted PM mass of $8 \%$ or an excess total PM mass calculation of $6 \%$.

The $\mathrm{Fe} / \mathrm{Na}^{+}$edge line methodology used to estimate $\mathrm{Na}^{+}$ and $\mathrm{Mg}^{2+}$ was conservative, minimising the subtraction from sea salt. This was partially compensated by using minimum values and the $\mathrm{Na}_{\mathrm{ss}}^{+} / \mathrm{Mg}_{\mathrm{ss}}^{2+}$ ratio in seawater. The edge line intercepts the $x$ axis at $\mathrm{Na}^{+}$levels within the range of values observed for periods without significant dust intrusions, in accordance with the fact that there is always sea-salt spray in this marine atmosphere (see Fig. 2a, where air masses without dust intrusions are represented by a blue rectangle). The points to the right of the edge line have excess $\mathrm{Na}^{+}$, by comparison with $\mathrm{Fe}$ in the edge line. This excess can have two origins: either it results from variability in the relative content of $\mathrm{Na}^{+}$in soil dust, or it is resultant from the variability in the contributions of sea salt. It is clear that the points at low $\mathrm{Fe}$ levels, within the blue rectangle, are only consequence from variability in sea-salt spray loading. On the right border of the blue rectangle, a pink straight line is drawn, parallel to the $\mathrm{Fe} /$ Ion edge lines. As all the measured points are within both lines, this is a strong indicator that $\mathrm{Na}^{+}$and $\mathrm{Mg}^{2+}$ increase, in relation to the edge lines, result mostly from variability in sea-salt input. The real value of the errors in this methodology is difficult to establish, but a change in the $\mathrm{Fe} / \mathrm{Na}^{+}$edge ratio of $10 \%$ would have no visible effect in the estimation of sea salt or soil dust by IMB.

The estimated value for non-carbonate carbonaceous matter depends strongly from the $\mathrm{OM} / \mathrm{OC}$ ratio. In the literature, values in the range 1.2-2.3 have been proposed. We used a ratio of 2.0 in the high end of the range because the sampling was performed at a background location, away from primary combustion sources, with plenty of time for oxidation and secondary formation. However, during dust episodes, important fractions of the organic material have a soil origin and for that less reliable information exists. As the carbonaceous fraction in PM mass is only $2 \%-6 \%$, errors in OM/OC ratio have only a small effect in total mass attribution, but important errors, of the order of $40 \%$, can result in the estimation of the carbonaceous mass if a OM/OC ratio of 1.6 is the correct assumption, instead of 2.0.

\section{Conclusions}

Atmospheric aerosol was collected during 1 year, as $\mathrm{PM}_{10}$, in air masses transported from north Africa to Cabo Verde islands and submitted to total mass, elemental, ionic and carbon content analysis. Two clear different aerosol seasons were observed: one in December-February, with frequent intrusions of dust from Africa (denoted dry haze), and the other in May-September, without direct African dust contamination (dust-free).

The application of IMB to the collected aerosol permitted the determination of six to seven source classes: insoluble dust, soluble dust, sea salt, secondary inorganic compounds from the reaction of atmospheric acidic precursors with sea salt, dust and ammonia, and carbonaceous matter.

The sum of calculated components only partially closed the mass balance, being $20 \%-30 \%$ of the measured $\mathrm{PM}_{10}$ total mass unaccounted. Consideration and estimation of particulate water content, based in bibliographic and thermodynamic assumptions, permitted an almost total closure of the mass balance. This outcome is diverse from most previous mass balance studies, such as those referred to in the section on mass balance methodologies, where mass closure was only partial. Therefore, the present IMB methodology permits a more well-based mass account and apportionment of formation processes and sources.

During the dry-haze season, dust contributed with around $80 \%$ to the aerosol mass loading, while in the dust-free period the main aerosol component was sea salt that constituted approximately $50 \%$ of the aerosol mass.

The IMB methodology was compared with PMF results applied to the same data set. In seasonal averaged terms, the outcomes of the two methodologies were comparable for the most important sources and formation processes. Comparison between individual samples showed, however, significant differences, principally for the sea-salt spray and the carbonaceous/combustion sources. Because of the overwhelming presence of dust in most samples, the PMF could not clearly separate dust from sea-salt sources. On the other hand, IMB could not discriminate soil organic matter from combustion emissions.

We can rely on the complementarity of both methods for the evaluation of sources contributing to atmospheric contamination, in circumstances of very high natural inputs of sea salt and desert dust particles, subject to atmospheric transformation during long-range transport. Utilisation of these two independent source apportionment methodologies adds confidence to the apportionment of an atmospheric aerosol with quite specific and uncommon characteristics.

Otherwise, source composition and contribution knowledge obtained with IMB can be used to complement the constrains already applied in the last versions of the PMF model (Amato and Hopke, 2012; Liu et al., 2015; Chen et al., 2018), in order to get more refined solutions than the original ones. Constraints can be created using specific ratios between two different species or mass balance equations derived from IMB techniques such as those performed in this study.

Data availability. The data used in this study are available in the Supplement. 
Supplement. The supplement related to this article is available online at: https://doi.org/10.5194/acp-18-13215-2018-supplement.

Author contributions. JC mounted the sampling station, collected the samples, analysed the carbonaceous and ionic fractions and participated in the treatment of data. SMA coordinated the analysis of elements and participated in the data treatment by PMF. TN coordinated the analysis of the mass and carbonaceous fraction, and participated in the treatment of the data. MA-S participated in the analysis of total mass and of elements by INAA. PC and MR were responsible for the analysis of elements by PIXE, and MR also participated in the paper discussion. MC coordinated the analysis of the ionic fraction and participated in data treatment and paper discussion. CA was responsible for the analysis of the organic fraction and participated in data treatment. FR was responsible for filter analysis by XRD. PS and BA coordinated the treatment of the data by PMF and participated in data treatment and paper elaboration. CP coordinated the CV-DUST project, was supervisor of $\mathrm{JC} \mathrm{PhD}$, developed the IMB methodology, treated the data and wrote the paper.

Competing interests. The authors declare that they have no conflict of interest.

Acknowledgements. The authors gratefully acknowledge the Portuguese Science Foundation through the project CV-DUST Atmospheric aerosol in the Cape Verde region: carbon and soluble fractions of $\mathrm{PM}_{10}$ (PTDD/AAC-CLI/100331/2008) and the $\mathrm{PhD}$ scholarship of João Cardoso. C2TN/IST/ULisboa authors gratefully acknowledge the FCT support through the UID/Multi/04349/2013 project.

Edited by: Chak K. Chan

Reviewed by: three anonymous referees

\section{References}

Alastuey, A., Querol, X., Castillo, S., Escudero, M., Avila, A., Cuevas, E., Torres, C., Romero, P.-M., Exposito, F., García, O., Pedro Diaz, J., Dingenen, R. V., and Putaud, J. P.: Characterisation of TSP and $\mathrm{PM}_{2.5}$ at Izaña and Sta. Cruz de Tenerife (Canary Islands, Spain) during a Saharan Dust Episode (July 2002), Atmos. Environ., 39, 4715-4728, https://doi.org/10.1016/j.atmosenv.2005.04.018, 2005.

Almeida, S. M., Pio, C. A., Freitas, M. C., Reis, M. A., and Trancoso, M. A.: Source apportionment of atmospheric urban aerosol based on weekdays/weekend variability: evaluation of road resuspended dust contribution, Atmos. Environ., 40, 2058-2067, https://doi.org/10.1016/j.atmosenv.2005.11.046, 2006a.

Almeida, S. M., Pio, C. A., Freitas, M. C., Reis, M. A., and Trancoso, M. A.: Approaching $\mathrm{PM}_{2.5}$ and $\mathrm{PM}_{2.5-10}$ source apportionment by mass balance analysis, principal component analysis and particle size distribution, Sci. Total Environ., 368, 663-674, https://doi.org/10.1016/j.scitotenv.2006.03.031, $2006 \mathrm{~b}$.

Almeida, S. M., Freitas, M. C., Reis, M., Pinheiro, T., Felix, P. M., and Pio, C. A.: Fifteen years of nuclear techniques ap- plication to suspended particulate matter studies, J. Radioanal. Nucl. Chem., 297, 347-356, https://doi.org/10.1007/s10967012-2354-1, 2013.

Almeida-Silva, M., Almeida, S. M., Freitas, M. C., Pio, C. A., Nunes, T., and Cardoso, J.: Impact of Sahara dust transport on Cape Verde atmospheric element particles. J. Toxicol. Env. Heal. A, 76, 240-251, https://doi.org/10.1080/15287394.2013.757200, 2013.

Almeida-Silva, M., Almeida, S. M., Cardoso, J., Nunes, T., Reis, M. A., Chaves, P. C., and Pio, C. A.: Characterization of the aeolian aerosol from Cape Verde by k(0)-INAA and PIXE, J. Radioanal Nucl. Chem., 300, 629-635, https://doi.org/10.1007/s10967014-2957-9, 2014.

Amato, F. and Hopke, P. K.: Source apportionment of the ambient $\mathrm{PM}_{2.5}$ across St. Louis using constrained positive matrix factorization, Atmos. Environ., 46, 329-337, https://doi.org/10.1016/j.atmosenv.2011.09.062, 2012

Amato, F., Alastuey, A., Karanasiou, A., Lucarelli, F., Nava, S., Calzolai, G., Severi, M., Becagli, S., Gianelle, V. L., Colombi, C., Alves, C., Custódio, D., Nunes, T., Cerqueira, M., Pio, C., Eleftheriadis, K., Diapouli, E., Reche, C., Minguillón, M. C., Manousakas, M.-I., Maggos, T., Vratolis, S., Harrison, R. M., and Querol, X.: AIRUSE-LIFE+: a harmonized PM speciation and source apportionment in five southern European cities, Atmos. Chem. Phys., 16, 3289-3309, https://doi.org/10.5194/acp16-3289-2016, 2016.

Andrews, E., Saxena, P., Musarra, S., Hildemann, L. M., Koutrakis, P., McMurry, P. H., Olmez, I., and White, W. H.: Concentration and Composition of Atmospheric Aerosols from the 1995 SEAVS Experiment and a Review of the Closure between Chemical and Gravimetric Measurements, J. Air Waste Manage. Assoc., 50, 648-664, https://doi.org/10.1080/10473289.2000.10464116, 2000.

Ashbaugh, L. L., Myrup, L. O., and Flocchini, R. G.: A principal component analysis of sulfur concentrations in the western United States, Atmos. Environ., 18, 783-791, https://doi.org/10.1016/0004-6981(84)90262-2, 1984.

Belis, C. A., Karagulian, F., Larsen, B. R., and Hopke, P. K.: Critical review and meta-analysis of ambient particulate matter source apportionment using receptor models in Europe, Atmos. Environ., 69, 94-108, https://doi.org/10.1016/j.atmosenv.2012.11.009, 2013.

Belis, C. A., Larsen, B. R., Amato, F., El Haddad, I., Favez, O., Harrison, R. M., Hopke, P. K., Nava, S., Paatero, P., Prevot, A., Quass, U., Vecchi, R., and Viana, M.: European Guide on Air Pollution Source Apportionment with Receptor Models, JRC Reference Report EUR 26080, Publication Office of the European Union, ISBN 978-92-79-32514-4, https://doi.org/10.2788/9332, 2014.

Blanchard, C.: Methods for attributing ambient air pollutants to emission sources, Annu. Rev. Energy Environ., 24, 329-365, https://doi.org/10.1146/annurev.energy.24.1.329, 1999.

Brunekreef, B. and Fosberg, B.: Epidemiological evidence of effects of coarse airborne particles on health, Eur. Respir. J., 26 , 309-318, https://doi.org/10.1183/09031936.05.00001805, 2005.

Buseck, P. R. and Pósfai, M.: Airborne minerals and related aerosol particles: Effects on climate and the environment, PNAS, 96, 3372-3379, https://doi.org/10.1073/pnas.96.7.3372, 1999. 
Canepari, S., Farao, C., Marconi, E., Giovannelli, C., and Perrino, C.: Qualitative and quantitative determination of water in airborne particulate matter, Atmos. Chem. Phys., 13, 1193-1202, https://doi.org/10.5194/acp-13-1193-2013, 2013.

Castillo, S., Moreno, T., Querol, X., Alastuey, A., Cuevas, E., Herrmann, L., Mounkaila, M., and Gibbons, W.: Trace element variation in size-fractionated African desert dusts, J. Arid Environ., 72, 1034-1045, https://doi.org/10.1016/j.jaridenv.2007.12.007, 2008.

Chen, J., Qiu, S., Shang, J., Wilfrid, O. M. F., Liu, X., Tian, H., and Boman J.: Impact of relative humidity and water soluble constituents of $\mathrm{PM}_{2.5}$ on visibility impairment in Beijing, China, Aerosol Air Qual. Res., 14, 260-268, 2014.

Chen, X. and Yu, J. Z.: Measurement of organic mass to organic carbon ratio in ambient aerosol samples using a gravimetric technique in combination with chemical analysis, Atmos. Environ., 41, 8857-8864, https://doi.org/10.1016/j.atmosenv.2007.08.023, 2007.

Chen, L.-W. A. and Cao, J.: $\mathrm{PM}_{2.5}$ Source Apportionment Using a Hybrid Environmental Receptor, Environ. Sci. Technol., 52, 6357-6369, https://doi.org/10.1021/acs.est.8b00131, 2018.

Chiapello, I., Bergametti, G., Chatenet, B., Bousquet, P., and Santos Soares, E.: Origins of African dust transported over northeastern tropical Atlantic, J. Geophys. Res., 102, 13701-13709, https://doi.org/10.1029/97JD00259, 1997.

Countess, R. J., Wolff, G. T., and Cadle, S. H.: The Denver Winter Aerosol: A Comprehensive Chemical Characterization, J. Air Pollut. Control Assoc., 30, 1194-1200, https://doi.org/10.1080/00022470.1980.10465167, 1980.

Dick, W. D., Saxena, P., and McMurry, P. H.: Estimation of water uptake by organic compounds in submicron aerosols measured during the Southeastern aerosol and visibility study, J. Geophys. Res., 105, 1471-1479, https://doi.org/10.1029/1999JD901001, 2000.

Eldred, B.: Internal memo to IMPROVE Staff, available at: http://vista.cira.colostate.edu/improve/Publications/GrayLit/ 023_SoilEquation/Soil_Eq_Evaluation.pdf (last access: $30 \mathrm{Au}-$ gust 2018), 2003.

Eltayeb, M. A. H., Injuk, J., Maenhaut, W., and Van Grieken, R. E.: Elemental Composition of Mineral Aerosol Generated from Sudan Sahara Sand, J. Atmos. Chem., 40, 247-273, https://doi.org/10.1023/A:1012272208129, 2001.

El-Zanan, H. S., Zielinska, B., Mazzoleni, L. R., and Hansen, D. A.: Analytical determination of the aerosol organic mass-toorganic carbon ratio, J. Air Waste Manag. Assoc., 59, 58-69, https://doi.org/10.3155/1047-3289.59.1.58, 2009.

Ervens, B., Turpin, B. J., and Weber, R. J.: Secondary organic aerosol formation in cloud droplets and aqueous particles (aqSOA): a review of laboratory, field and model studies, Atmos. Chem. Phys., 11, 11069-11102, https://doi.org/10.5194/acp-1111069-2011, 2011.

Formenti, P., Andreae, M. O., Lange, L., Roberts, G., Cafineyer, J., Rajta, I., Maenhaut, W., Holben, B. N., Artaxo, P., and Lelieveld, J.: Saharan dust in Brazil and Suriname during the Large-Scale Biosphere-Atmosphere Experiment in Amazonia (LBA) - Cooperative LBA Regional Experiment (CLAIRE) in March 1998, J. Geophys. Res., 106, 14919-14934, https://doi.org/10.1029/2000JD900827, 2001.
Formenti, P., Elbert, W., Maenhaut, W., Haywood, J., and Andrea, M. O.: Chemical composition of mineral dust aerosol during Saharan Dust Experiment (SHADE) airborne campaign in the Cape Verde region, September 2000, J. Geophys Res., 108, 8576, https://doi.org/10.1029/2002JD002648, 2003.

Gama, C., Tchepel, O., Baldasano, J., Basart, S., Ferreira, J., Pio, C., Cardoso, J., and Borrego, C.: Seasonal patterns of Saharan dust over Cape Verde - a combined approach using observations and modelling, Tellus B, 67, 24410, https://doi.org/10.3402/tellusb.v67.24410, 2015.

Genga, A., Ielpo, P., Siciliano, T., and Siciliano, M.: Carbonaceous particles and aerosol mass closure in $\mathrm{PM}_{2.5}$ collected in a port city, Atmos. Res., 183, 245-254, https://doi.org/10.1016/j.atmosres.2016.08.022, 2017.

Ginoux, P., Prospero, J. M., Gill, T. E., Hsu, N. C., and Zhao, M.: Global-scale attribution of anthropogenic and natural dust sources and their emission rates based on MODIS deep blue aerosol products, Rev. Geophys., 50, RG3005, https://doi.org/10.1029/2012RG000388, 2012.

Goodman, A. L., Underwood, G. M., and Grassian, V. H.: A laboratory study of the heterogeneous reaction of nitric acid on calcium carbonate particles, J. Geophys. Res., 105, 29053-29064, https://doi.org/10.1029/2000JD900396, 2000.

Grigoratos, T., Samara, C., Voutsa, D., Manoli, E., and Kouras, A.: Chemical composition and mass closure of ambient coarse particles at traffic and urban-background sites in Thessaloniki, Greece, Environ Sci. Pollut. Res., 21, 7708-7722, https://doi.org/10.1007/s11356-014-2732-z, 2014.

Guieu, C., Loye-Pilot, M.-D., Ridame, C., and Thomas, C.: Chemical characterization of the Saharan dust end-member: Some biogeochemical implications for the western Mediterranean Sea, J. Geophys. Res., 107, D15, ACH 5-1-ACH 5-11, https://doi.org/10.1029/2001JD000582, 2002.

Guinot, B., Cachier, H., and Oikonomou, K.: Geochemical perspectives from a new aerosol chemical mass closure, Atmos. Chem. Phys., 7, 1657-1670, https://doi.org/10.5194/acp-7-1657-2007, 2007.

Harrison, R. M., Jones, A. M., and Lawrence, R. G.: A pragmatic mass closure model for airborne particulate matter at urban background and roadside sites, Atmos. Environ., 37, 4927-4933, https://doi.org/10.1016/j.atmosenv.2003.08.025, 2003.

Henry, R. C., Lewis, C. W., Hopke, P. K., and Williamson, H. J.: Review of receptor model fundamentals, Atmos. Environ., 18, 1507-1515, https://doi.org/10.1016/0004-6981(84)90375-5, 1984.

Hopke, P. K.: Receptor Modelling in Environmental Chemistry, Wiley \& Sons, NY, 1985.

Japar, S. M., Szkarlat, A. C., Gorse Jr., R. A., Heyerdahl, E. K., Johnson, R. L., Rau, J. A., and Huntzicker, J. J.: Comparison of Solvent Extraction and Thermal Optical Carbon Analysis Methods: Application to Diesel Vehicle Exhaust Aerosol, Environ. Sci. Technol., 18, 231-234, https://doi.org/10.1021/es00122a004, 1984.

Journet, E., Balkanski, Y., and Harrison, S. P.: A new data set of soil mineralogy for dust-cycle modeling, Atmos. Chem. Phys., 14, 3801-3816, https://doi.org/10.5194/acp-14-3801-2014, 2014.

Kandler, K., Schütz, L., Deutscher, C., Eber, M., Hofmann, H., Jäckel, S., Jaenicke, R., Knippertz, P., Lieke K., Massling, A., Petzold, A., Schladitz, A., Weinzierl, B., Wiedensohler, 
A., Zorn, S., and Weinbruch, S.: Size distribution, mass concentration, chemical and mineralogical composition and derived optical parameters of the boundary layer aerosol at Tinfou, Morocco, during SAMUM 2006, Tellus B, 61, 32-50, https://doi.org/10.1111/j.1600-0889.2008.00385.x, 2009.

Kitamori, Y., Mochida, M., and Kawamura, K.: Assessment of the aerosol water content in urban atmospheric particles by the hygroscopic growth measurements in Sapporo, Japan, Atmos. Environ., 43, 3416-3423, https://doi.org/10.1016/j.atmosenv.2009.03.037, 2009.

Liu, G. R., Shi, G. L., Tian, Y. Z., Wang, Y. N., Zhang, C. Y., and Feng, Y. C.: Physically constrained source apportionment (PCSA) for polycyclic aromatic hydrocarbon using the Multilinear Engine 2-species ratios (ME2-SR) method, Sci. Total Environ., 502, 16-21, https://doi.org/10.1016/j.scitotenv.2014.09.011, 2015.

Lohmann, U. and Feichter, J.: Global indirect aerosol effects: a review, Atmos. Chem. Phys., 5, 715-737, https://doi.org/10.5194/acp-5-715-2005, 2005.

Malm, W. C., Sisler, J. F., Huffman, D., Eldred, R. A., and Cahill, T. A.: Spatial and seasonal trends in particle concentration and optical extinction in the United States, J. Geophys. Res., 99, 13471370, https://doi.org/10.1029/93JD02916, 1994.

Mason B. and Moore C. B.: Principles of Geochemistry, 4 Edn., Wiley \& Sons, New York, 1982.

Mirante, F., Salvador, P., Pio, C., Alves, C., Artinano, B., Caseiro, A., and Revuelta, M. A.: Size fractionated aerosol composition at roadside and background environments in the Madrid urban atmosphere, Atmos. Res., 138, 278-292, https://doi.org/10.1016/j.atmosres.2013.11.024, 2014.

Moreno, T., Querol, X., Castillo, S., Alastuey, A., and Cuevas, E.: Geochemical variations in Aeolian mineral particles from the Sahara-Sahel dust corridor, Chemosphere, 65, 261-270, https://doi.org/10.1016/j.chemosphere.2006.02.052, 2006.

Nenes, A., Pandis, S. N., and Pilinis, C.: ISORROPIA: A new thermodynamic equilibrium model for multiphase multicomponent inorganic aerosols, Aquat. Geoch., 4, 123-152, https://doi.org/10.1023/A:1009604003981, 1998a.

Nenes, A., Pilinis, C., and Pandis, S. N.: Continued Development and Testing of a New Thermodynamic Aerosol Module for Urban and Regional Air Quality Models, Atmos. Environ., 33, 1553-1560, https://doi.org/10.1016/S1352-2310(98)003525, 1998b.

Paatero, P.: The multilinear engine - a table-driven least squares program for solving multilinear problems, including the n-way parallel factor analysis model, J. Comput. Graph Stat., 8, 854888, https://doi.org/10.1080/10618600.1999.10474853, 1999.

Paatero, P. and Tapper, U.: Positive matrix factorization: A non-negative factor model with optimal utilization of error estimates of data values, Environmetrics, 5, 111-126, https://doi.org/10.1002/env.3170050203, 1994.

Perrino, C., Canepari, S., and Catrambone, M.: Comparing the Performance of Teflon and Quartz Membrane Filters Collecting Atmospheric PM: Influence of Atmospheric Water, Aerosol Air Qual. Res., 13, 137-147, https://doi.org/10.4209/aaqr.2012.07.0167, 2013.

Pio, C., Cerqueira, M., Harrison, R., Nunes, T., Mirante, F., Alves, C., Oliveira, C., Sanchez de la Campa, A., Artíñano, B., and Matos, M.: OC/EC Ratio Observations In Europe: Re-
Thinking The Approach For Apportionment Between Primary And Secondary Organic Carbon, Atmos. Environ., 45, 61216132, https://doi.org/10.1016/j.atmosenv.2011.08.045, 2011.

Pio, C. A. and Lopes, D.: Chlorine loss from marine aerosol in a coastal atmosphere, J. Geophys. Res., 103, 25263-25269, https://doi.org/10.1029/98JD02088, 1998.

Pio, C. A., Ramos, M. O., and Duarte, A. C.: Measurement of Carbonates in Atmospheric Aerosols by Acidification and NDIR Analysis of Evolved $\mathrm{CO}_{2}$, in: Physico-Chemical Behaviour of Atmospheric Pollutants, edited by: Angeletti, G. and Restelli, G., Report EUR 15609/1 EN, European Commission, Brussels, Vol. 1, 712-717, 1994

Pope III, C. A.: Review, Epidemiological basis for particulate air pollution health standards, Aerosol Sci. Tech., 32, 4-14, https://doi.org/10.1080/027868200303885, 2000.

Pöschl, U.: Atmospheric aerosols: Composition, transformation climate and health effects, Angew. Chem. Int. Ed., 44, 7520-7540, https://doi.org/10.1002/anie.200501122, 2005.

Raes, F., Van Dingenen, R., Vignati, E., Wilson, J., Putaud, J. P., Seinfeld, J. H., and Adams, P.: Formation and cycling of aerosols in the global troposphere, Atmos. Environ., 34, 42154240, https://doi.org/10.1016/S1352-2310(00)00239-9, 2000.

Ramanathan, V., Crutzen, P. J., Kiehl, J. T., and Rosenfeld, D.: Aerosols, Climate, and the Hydrological Cycle, Science, 294, 2119-2124, https://doi.org/10.1126/science.1064034, 2001.

Rees, S. L., Robinson, A. L., Khlystov, A., Stanier, C. O., and Pandis, S. N.: Mass Balance Closure and the Federal Reference Method for $\mathrm{PM}_{2.5}$ in Pittsburgh, Pennsylvania, Atmos. Environ., 38, 3305-3318, https://doi.org/10.1016/j.atmosenv.2004.03.016, 2004.

Reff, A., Eberly, S. I., and Bhave, P. V.: Receptor Modeling of Ambient Particulate Matter Data Using Positive Matrix Factorization: Review of Existing Methods, J. Air Waste Manag. Assoc., 57, 146-154, https://doi.org/10.1080/10473289.2007.10465319, 2007.

Remoundaki, E., Papayannis, A., Kassomenos, P., Mantas, E., Kokkalis, P., and Tsezos, M.: Influence of Saharan Dust Transport Events on $\mathrm{PM}_{2.5}$ Concentrations and Composition over Athens, Water Air Soil Pollut., 224, 1373, https://doi.org/10.1007/s11270-012-1373-4, 2013.

Rogge, W. F., Hildemann, L. M., Mazurek, M. A., Cass, G. R., and Simoneit B. R. T.: Sources of Fine Organic Aerosol, 4. Particulate Abrasion Products from Leaf Surfaces of Urban Plants, Environ. Sci. Technol., 27, 2700-2711, https://doi.org/10.1021/es00049a008, 1993a.

Rogge, W. F., Mazurek, M. A., Hildemann, L. M., and Cass, G. R.: Quantifcation of Urban Organic Aerosols at a Molecular Level: Identification, Abundance and Seasonal Variation, Atmos. Environ., 27, 1309-1330, https://doi.org/10.1016/09601686(93)90257-Y, 1993b.

Russel L. M.: Aerosol Organic-Mass-to-Organic-Carbon Ratio Measurements, Environ. Sci. Technol., 37, 2982-2987, https://doi.org/10.1021/es026123w, 2003.

Salvador, P., Almeida, S. M., Cardoso, J., Almeida-Silva, M., Nunes, T., Cerqueira, M., Alves, C., Reis, M. A., Chaves, P. C., Artinano, B., and Pio, C.: Composition and origin of $\mathrm{PM}_{10}$ in Cape Verde: Characterization of longrange transport episodes, Atmos. Environ., 127, 326-339, https://doi.org/10.1016/j.atmosenv.2015.12.057, 2016. 
Scheuvens, D., Kandler, K., Ebert, M., and Weinbruch, S.: Bulk composition of northern African dust and its source sediments - A compilation, Earth-Sci. Rev., 116, 170-194, https://doi.org/10.1016/j.earscirev.2012.08.005, 2013.

Schuttlefield, J. D., Cox, D., and Grassian, V. H.: An Investigation of water uptake on Clays Minerals Using ATR-FTIR Spectroscopy Coupled with Quartz Crystal microbalance measurements, J. Geophys. Res., 112, D21303, https://doi.org/10.1029/2007JD008973, 2007.

Sciare, J., Oikonomou, K., Cachier, H., Mihalopoulos, N., Andreae, M. O., Maenhaut, W., and Sarda-Estève, R.: Aerosol mass closure and reconstruction of the light scattering coefficient over the Eastern Mediterranean Sea during the MINOS campaign, Atmos. Chem. Phys., 5, 2253-2265, https://doi.org/10.5194/acp-5-22532005, 2005.

Seinfeld, J. H. and Pandis, S. N.: Atmospheric Chemistry and Physics: From Air Pollution to Climate Change, 2nd Edn., Wiley, Hoboken, NJ, 1998.

Sempere, R. and Kawamura, K.: Comparative Distributions of Dicarboxylic Acids and Related Polar Compounds in Snow, Rain and Aerosols from Urban Atmosphere, Atmos. Environ., 28, 449-459, https://doi.org/10.1016/1352-2310(94)90123-6, 1994.

Speer, R. E., Barnes, H. M., and Brown, R.: An instrument for measuring the liquid content of aerosols, Aerosol Sci. Technol., 27, 50-61, https://doi.org/10.1080/02786829708965457, 1997.

Speer R. E., Edney E. O., and Kleindienst T. E.: Impact of organic compounds on the concentrations of liquid water in ambient $\mathrm{PM}_{2.5}$, Aerosol Science, 34, 63-77, https://doi.org/10.1016/S0021-8502(02)00152-0, 2003.

Stanier, C., Khlystov, A., Chan, W. R., Mandiro, M., and Pandis, S. N.: A method for the in-situ measurement of aerosol water content of ambient aerosols: The Dry-Ambient Aerosol Size Spectrometer (DAASS), Aerosol Sci. Technol., 38, 215-228, https://doi.org/10.1080/02786820390229525, 2004.
Tanaka, T. Y. and Chiba, M.: A numerical study of the contributions of dust source regions to the global dust budget, Global Planet Change, 52, 88-104, https://doi.org/10.1016/j.gloplacha.2006.02.002, 2006.

Tang, I. N. and Munkelwitz, H. R.: Water activities, densities, and refractive indices of aqueous sulfates and sodium nitrate droplets of atmospheric importance, J. Geophys. Res., 99, 18801-18808, https://doi.org/10.1029/94JD01345, 1994.

Tang, I. N., Tridico, A. C., and Fung, K. H.: Thermodynamic and optical properties of sea salt aerosols, J. Geophysical Res., 102, 23269-23275, https://doi.org/10.1029/97JD01806, 1997.

Tobias, A., Perez, L., Diaz J., Linares, C., Pey, J., Alastuey, A., and Querol, X.: Short term effects of particulate matter on total mortality during Saharan dust outbreaks: a case-crossover analysis in Madrid (Spain), Sci. Total Environ., 412-413, 386-389, https://doi.org/10.1016/j.scitotenv.2011.10.027, 2011.

Tsyro, S. G.: To what extent can aerosol water explain the discrepancy between model calculated and gravimetric $\mathrm{PM}_{10}$ and $\mathrm{PM}_{2.5}$ ?, Atmos. Chem. Phys., 5, 515-532, https://doi.org/10.5194/acp-5-515-2005, 2005.

Turekian, K. K.: Oceans, Prentice-Hall, Englewood Cliffs, NJ, 1968.

Turpin, B. J. and Lim, H. J.: Species Contributions to $\mathrm{PM}_{2.5}$ Mass Concentrations: Revisiting Common Assumptions for Estimating Organic Mass, Aerosol Sci. Technol., 35, 602-610, https://doi.org/10.1029/97JD01806, 2001.

Watson, J. G., Zhu, T., Chow, J. C., Engelbrecht, J., Fujita, E. M., and Wilson, W. E.: Receptor modeling application framework for particle source apportionment, Chemosphere, 49, 1093-1136, https://doi.org/10.1016/S0045-6535(02)00243-6, 2002.

Wedepohl, K. H.: The composition of the continental crust, Geochim. Cosmochim. Ac., 59, 1217-1232, https://doi.org/10.1016/0016-7037(95)00038-2, 1995.

$\mathrm{Xu}$, J., Imre, D., McGraw, R., and Tang, I.: Ammonium sulphate: Equilibrium and metastability phase diagrams from 40 to $-50{ }^{\circ} \mathrm{C}$, J. Phys. Res. B, 102, 7462-7469, https://doi.org/10.1021/jp981929x, 1998. 